\title{
MEASUREMENT OF MIGRATION AREA AND ANISOTROPY IN A MOCKUP OF THE EL-4 LATTICE
}
A.E. Dunklee
W. B. Rogers

SRL

RECORD COPY

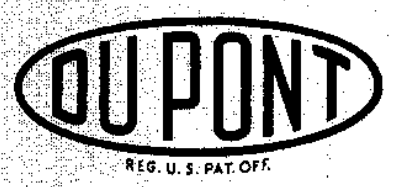

Savannah River Laboratory

Aiken, South Carolina 


\title{
LEG A L NOTICE
}

This report was prepared as an account of Government sponsored work. Neither the United States, nor the Commission, nor any person acting on behalf of the Commission:

A. Makes any warranty or representation, expressed or implied, with respect to the accuracy, completeness, or usefulness of the information contained in this report, or that the use of any information, apparatus, method, or process disclosed in this report may not infringe privately owned rights; or

B. Assumes any liabllities with respect to the use of, or for damages resulting from the use of any information, apparatus, method, or process disclosed in this report.

As used in the above, "person acting on behalf of the Commission" includes any employee or contractor of the Commission, or employee of such contractor, to the extent that such employee or contractor of the Commission, or employee of such contractor prepares, disseminates, or provides access to, any information pursuant to his employment or contract with the Commission, or his employment with such contractor.

\author{
Printed in USA. Price $\$ 3.00$
}

Avallable from the Clearinghouse for Federal Sclentific

and Technical Information, National Bureau of Standards,

U. S. Department of Commerce, Springfield, Virginia 


\title{
MEASUREMENT OF MIGRATION AREA AND ANISOTROPY IN A MOCKUP OF THE EL -4 LATTICE
}

\author{
by \\ Albert E. Dunklee \\ Warren B. Rogers \\ Work done by \\ F. D. Benton \\ G. F. O'Neill \\ A. E. Dunklee \\ W. B. Rogers \\ W. E. Graves \\ S. V. Topp \\ C. E. Jewell \\ P. A. Lourme* \\ * Official observer representing Commissariat \\ A L'Energie Atomique, Saclay, France.
}

Approved by

J. L. Crandall, Research Manager

Experimental Physics Division

November 1964

\author{
E. 1. DU PONT DE NEMOURS \& COMPANY \\ SAVANNAH RIVER LABORATORY \\ AIKEN, SOUTH CAROLINA \\ CONTRACT AT(07.2)-1 WITH THE \\ UNITED STATES ATOMIC ENERGY COMMISSION
}




\section{ABSTRACT}

Nuclear parameters of the lattice for the French power reactor, EL-4, were determined in mockup lattices at the Savannah River Laboratory. The reactor is to be $\mathrm{D}_{2} \mathrm{O}$ moderated, gas cooled, and fueled with $\mathrm{UO}_{2}$ rod bundles. The mockup lattice had a square lattice pitch of $23.09 \mathrm{~cm}$ and was fueled by 19-rod clusters of $1.27 \mathrm{~cm}$ diameter natural uranium rods inside a1r-filled $12.7-\mathrm{cm}$ diameter housing tubes. Bucklings were determined for various pile shapes by measured flux profiles. Detalled studies were made of the diffusion properties of the lattice with emphasis on the anisotropic diffusion due to the neutron streaming in the alr-filled channels. Such studies included determination of the axial migration area by neutron polsoning techniques as well as by observation of the neutron kinetics of the pile on stable positive periods. Ratios of axial to radial migration areas were deduced from the buckling measurements on the different shaped plles. Measurements of radial and axial diffusion coefficlents were made by activation techniques and by measurements of the reactivity effect of introducing $\mathrm{D}_{2} \mathrm{O}$ into coolant channels of selected pile positions. Agreement of the measurements with theoretical predictions was generally good. 


\section{CONTENTS}

Page

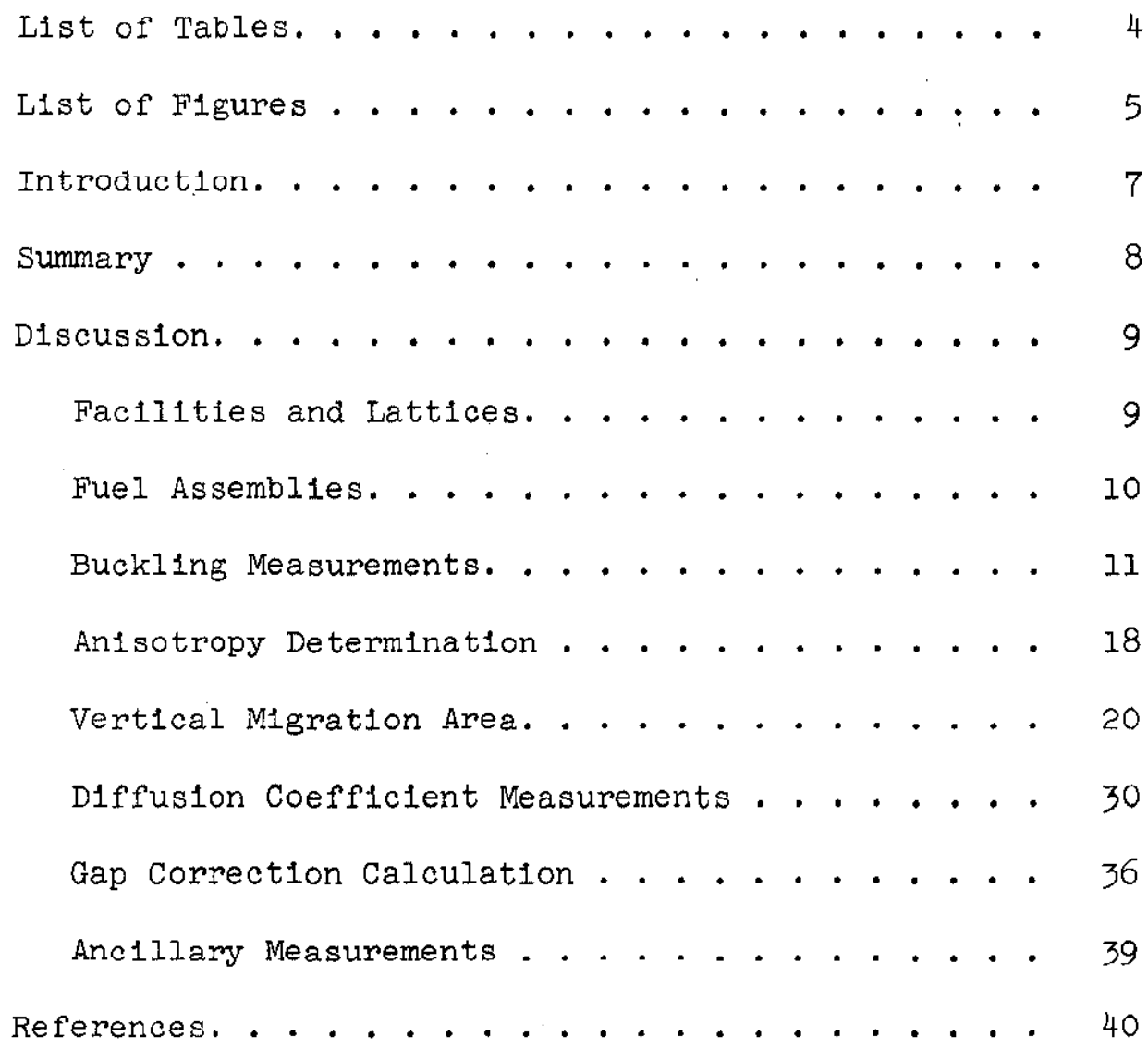




\section{LIST OF TABLES}

Table

$\underline{\text { Page }}$

I Comparison of EL-4 Lattice Dimensions

w1th PDP Mockup. . . . . . . . . 7

II Fuel Loadings in PDP . . . . . . . . . . . . 9

III Results of Flux Mapping Irradiations and Data Fltting in PDP Loadings . . . . . . 12

IV Summary of Measured Bucklings and Corrections in PDP Loadings. . . . . . . . . . . 14

V Vertical Flux Traverse Results in PDP Loading No. 1. . . . . . . . . . . . 16

VI $\kappa_{\mathrm{z}}{ }^{2}$ Measurements in the SE ........ 17

VII Radial Buckling Measurements in the SE . . 18

VIII Input Parameters for Calculation of Migration Area An1sotropy. . . . . . . . . . . 19

IX Ratio of Average Neutron Density in Copper Tubes to Average Neutron Density in Fuel, as Measured by Copper Folls . . . . . . . 21

$X \quad$ Flux Welghting Copper Tubes and Fuel Assemblles . . . . . . . . . . . 22

XI $\Delta f / f$ due to Addition of Copper Tubes to Lattice. . . . . . . . . . . . . 23

XII $\left(\mathrm{L}_{\mathrm{z}}{ }^{2}+\tau_{\mathrm{z}}\right)$ from Copper Polsoning Method. . . 25

XIII Perlod Measurements in PDP ........ 28

XIV Sensitivity of $-\Delta \mathrm{k}_{e f f} / \mathrm{B}_{z}{ }^{2}$ to Changes in $\delta$ and T............. 28

XV Parameters Used in Obta1ning $\left(I_{z}{ }^{2}+\tau_{z}\right)$ from Kinetics Experiments. . . . . . . . 29

XVI Migration Area by Period Reactivity Measurements ......... . 30

XVII Summary of Palmedo-Benoist $D_{r} / D_{m}$ Measurements........... 33

XVIII Measured Data, Persson 8D/D Measurements . . 35

XIX Results of Persson $\delta D / D$ Measurements in PDP. 36 


\section{LIST OF FIGURES}

Flgure

Page

1 Isometric Drawing of Process Development

Plle............... 42

2 Quadrant of PDP Loading No. 1 - 332 Fuel

Assemblies . . . . . . . . . 4 43

3 Quadrant of PDP Loading No. 2 - 332 Fuel

Assemblies, 156 Copper Tubes. . . . . . 44

4 Quadrant of PDP Loading No. 3 - 332 Fuel

Assemblies, 301 Copper Tubes. . . . . . 45

5 Quadrant of PDP Loading No. 4 - 216 Fuel Assemblies, $\mathrm{D}_{2} \mathrm{O}$ Reflector . . . . . 46

6 Quadrant of PDP Loading No. 5 - 120 Fuel Assemblies, $\mathrm{D}_{2} \mathrm{O}$ Reflector . . . . . . 47

7 Quadrant of PDP Loading No. 6 - 120 Fuel Assemblies, I1-Al Polsoned Reflector. . . 48

8 Quadrant of PDP Loading No. 7 - 156 Fue] Assemblies, 160 Steel P1pe Assemblies... . 49

9 Quadrant of PDP Loading No. 8 - 88 Fuel Assemblies, $\mathrm{D}_{2} \mathrm{O}$ Reflector . . . . . . 50

10 Cross Section of Steel Pipe Absorber Assembly. . . . . . . . . . . 51

11 Isometric View of Standard P1le and Exponential Tank. . . . . . . . 52 SE Loadings . . . . . . . . . . . 53

N1neteen Rod $\mathrm{UO}_{2}$ Fuel Assembly. . . . . 54

19 Fuel Centered Lattice, Palmedo-Beno1st Method for $D_{r} / D_{m} \cdot . . . . . . . . .660$ 
20 Moderator Centered Lattice, Palmedo-Benolst Method for $D_{r} / D_{m}$........... 61

21 Palmedo-Benolst Measurement of $\mathrm{D}_{\mathrm{r}} / \mathrm{D}_{\mathrm{m}}$ in PDP. ............. 62

22 Test Fuel Positions $\delta \mathrm{D} / \mathrm{D}$ Measurements in PDP. . . . . . . . . . . . 63

23 Corrected Fo1l Activations Across Fuel Gap . . . . . . . . . . . . 64

$24 \Delta \mathrm{B}_{\mathrm{z}}{ }^{2}$ due to Fuel Gap vs Vertical Buckling . 65

25 Cell Traverse with Copper W1re. . . . . 66

26 Reflector Savings.......... 67 


\section{MEASUREMENT OF MIGRATION AREA AND \\ ANISOTROPY IN A MOCKUP OF THE EL -4 LATTICE}

\section{INTRODUCTION}

As part of 1 ts program to develop nuclear power reactors, the Atomic Energy Commission of France (CEA) is bullding a large, $\mathrm{D}_{2} \mathrm{O}$-moderated, gas-cooled power reactor, the EL-4 $(1,2)$. The EL-4 is almost 1dentical in size with the Process Development Pile (PDP) ${ }^{(3)}$ at Savannah River Laboratory, and the proposed EL-4 fuel assemblies are quite similar to some experimental fuel assemblies avallable at Savannah River. It thus appeared that the PDP might provide a ready made nuclear mockup of the EL-4 which could yleld valuable information regarding the nuclear properties of gas-cooled lattices used in the EL-4.

A serles of experiments was designed to take advantage of the SRL facilities in (a) providing a partial mockup of the EI-4 latt1ce and (b) obtalning general physics information on gas-cooled $\mathrm{D}_{2} \mathrm{O}$ reactors. The principal areas of interest were the anisotropy and changes in migration area due to neutron streaming in the gas passages.

Two SRL facllities were proposed for these experiments; the Process Development Plle (PDP), and the Subcritical Experiment (SE) ${ }^{(4)}$, the exponential facility at SRL. Table I compares some of the dimensions of the EL-4 lattice mockup in the PDP w1th the corresponding EL-4 dimensions.

\section{TABLE I}

Comparison of EL-4 Lattice Dimensions w1th PDP Mockup

\begin{tabular}{|c|c|c|}
\hline Component & $E L-4$ & PDP \\
\hline Vessel diameter, $\mathrm{cm}$ & 480 & 494 \\
\hline Fuel assembly & $\begin{array}{l}19 \text { rods, } \\
\text { natural and } \\
\text { enriched } \mathrm{UO}_{2}\end{array}$ & $\begin{array}{l}19 \text { rods, } \\
\text { natural } \mathrm{UO}_{2}\end{array}$ \\
\hline Fuel rod diameter, $\mathrm{mm}$ & 11 or 13 & $12 \cdot 7$ \\
\hline $\begin{array}{l}\text { Fuel housing tube } \\
\text { diameter, } \mathrm{cm}\end{array}$ & 11.0 & 12.7 \\
\hline Lattice p1tch (square), $\mathrm{cm}$ & 23.0 & 23.09 \\
\hline
\end{tabular}




\section{SUMMARY}

Under a contract between the French Atom1c Energy Commission and the United States A. E. C., a set of experiments was performed at the Savannah R1ver Laboratory in support of the EL-4, a French nuclear power reactor prototype under construction. The primary objectives of the experiments were to determine the migration area and the lattice anisotropy for a lattice similar to that proposed for the EL-4.

The migration area was determined by two methods; the polsoned moderator technique using copper tubes as the poison, and the period reactivity technique. A welghted average of $483 \pm 14 \mathrm{~cm}^{2}$ was determined for $\left(\mathrm{I}_{\mathrm{z}}{ }^{2}+\tau_{\mathrm{z}}\right)$ by the polsoned moderator technique; the period reactivity measurements gave a value of $492 \pm 11 \mathrm{~cm}^{2}$.

Migration area an1sotropy was determined by measuring the buckling of the lattice for three different core shapes In the critical facility (PDP), and for one core shape in the exponent1al fac1lity (SE). The anisotropy, $\mathrm{M}_{\mathrm{z}}{ }^{2} / \mathrm{M}_{\mathrm{r}}{ }^{2}$, was $1.16 \pm 0.01$ using the critical and exponential results together, and $1.13 \pm 0.03$ using only the results of the crit1cal measurements.

A method developed by Palmedo and Benolst for determining the radial diffusion coefficlent of a lattice was applied to these experiments. The method presents an interesting approach to the study of the interaction of the microscoplc and macroscoplc fluxes and to the determination of the diffusion coefficient. The radial diffusion coefficlent determined by this method agrees quite well with calculations.

A series of experiments using substitution techniques was applied toward obtaining the ratio of the vertical to radial diffusion coefficlents. Although not entirely successful, the measurements provide useful information regarding the application of this method to volded lattices.

Data on the worth of the $\mathrm{D}_{2} \mathrm{O}$ reflector were obtained for reflector thicknesses up to $125 \mathrm{~cm}$. Because the ELm 4 will be operated with a reflector, these data should ald in the evaluation of the reflector effectiveness. 


\section{DISCUSSION}

\section{FACILITIES AND LATTICES}

\section{Process Development Pile}

The $P D P^{(3)}$ and 1ts chlef auxiliaries are 1llustrated in Flgure 1. The reactor vessel is a bare, stalnless steel tank with an 1nside dlameter of $494 \mathrm{~cm}$. Its effective helght is controlled by the $\mathrm{D}_{2} \mathrm{O}$ level and in these experiments was limited to $274 \mathrm{~cm}$ by the fuel assembly length. The mockup EL-4 fuel assemblies, described in a following section, were always loaded into the reactor on a square lattice pitch of $23.09 \mathrm{~cm}$, center to center. Loadings were of several different sizes, ranging from 88 to 332 fuel assemblies, with varlous amounts of reflector. The loadings are shown in Figures 2 through 9 and are briefly described in Table II. The polson rod boundary in loading No. 6 (Figure 7) consisted of $2.54 \mathrm{~cm}$ diameter, aluminum-clad, L1-Al alloy rods, w1th a lithlum concentration of $4.9 \mathrm{wt} \%$. These rods were arranged on a $11.53 \mathrm{~cm}$ square p1tch adjacent to the fuel and on a $23.09 \mathrm{~cm}$ square pitch in the outer region. The outer region in loading No. 7 (Figure 8) was poisoned with steel pipe assemblies $275 \mathrm{~cm}$ long on a $23.09 \mathrm{~cm}$ square pitch. These assembiles, 1llustrated in Flgure 10, were selected to have approximately the same neutron diffusion and absorption properties as the fuel.

The moderator 1sotop1c pur1ty ranged from 99.57 to $99.54 \mathrm{~mol} \% \mathrm{D}_{2} \mathrm{O}$ during the experiments; moderator temperature was 20 to $22^{\circ} \mathrm{C}$.

\section{TABIE II}

\section{Fuel Loadings in PDP}

\begin{tabular}{|c|c|c|c|}
\hline $\begin{array}{l}\text { Loading } \\
\text { No, }\end{array}$ & $\begin{array}{l}\text { No. of Fuel } \\
\text { Assemblies }\end{array}$ & $\begin{array}{c}\text { Reflector*, } \\
\text { cm }\end{array}$ & Remarks \\
\hline 1 & 332 & 10 & Full pile load \\
\hline 2 & 332 & 10 & $\begin{array}{l}\text { Latt1ce poisoned w1th } \\
156 \text { copper tubes }\end{array}$ \\
\hline 3 & 332 & 10 & $\begin{array}{l}\text { Lattice polsoned with } \\
301 \text { copper tubes }\end{array}$ \\
\hline 4 & 216 & 50.4 & Reflector unpolsoned \\
\hline 5 & 120 & 100.6 & Reflector unpolsoned \\
\hline 6 & 120 & $\sim 10$ & $\begin{array}{l}\text { Thin reflector region. } \\
\text { Outer region polsoned } \\
\text { with } L 1-A] \text { rods }\end{array}$ \\
\hline 7 & 156 & None & $\begin{array}{l}\text { Outer region polsoned } \\
\text { with steel pipe } \\
\text { asemblies }\end{array}$ \\
\hline 8 & 88 & 122 & Reflector unpolsoned \\
\hline rad & $\begin{array}{l}\text { unpolso } \\
\text { core ar }\end{array}$ & $\begin{array}{l}\mathrm{D}_{2} \mathrm{O} \text { region } \\
\text { ank wall. }\end{array}$ & between cylindricized \\
\hline
\end{tabular}


Subcritical Experiment and Standard Pile

An 1sometric view of the Subcritical Experiment $(\mathrm{SE})^{(4)}$ and its neutron source, the Standard P1le $(\mathrm{SP})^{(5)}$, is shown in Figure 11. The $S E$ is an aluminum tank $153 \mathrm{~cm}$ in diameter and approximately $210 \mathrm{~cm}$ high. The tank wall is $0.953 \mathrm{~cm}$ thick and is covered on the outslde by a cadmlum sheet $0.16 \mathrm{~cm}$ thick. The tank rests on a graphite thermalizing column approximately $46 \mathrm{~cm}$ high and $153 \mathrm{~cm}$ in diameter. The SP Is an enriched uranium reactor, graphite moderated, and $\mathrm{H}_{2} \mathrm{O}$ cooled. The fuel and coolant are contalned in an aluminum annulus approximately $46 \mathrm{~cm}$ in diameter, $10 \mathrm{~cm}$ thick, and $46 \mathrm{~cm}$ long located in the center of the $153 \mathrm{~cm}$ cube of graphite.

The two different loadings used in the SE measurements are shown in Figure 12. In both loadings the fuel assemblies were arranged at the $23.09 \mathrm{~cm}$ square latt1ce pitch. In one loading, however, a fuel assembly was centered in the SE tank (Figure 12A) while in the other an interstitlal lattice point was centered in the tank (Figure 12B). These two loadings are designated fuel-centered and moderator-centered, respectively.

\section{FUEL ASSEMBLIES}

The fuel assemblies used in the measurements in the PDP are shown in Figure 13. They consisted of 19 uranium oxide rods arranged in hexagonally shaped clusters with $1.65 \mathrm{~cm}$ center-to-center rod spacing. The natural uranium oxide rods consisted of sintered $\mathrm{UO}_{2}$ pellets $1.27 \mathrm{~cm}$ in diameter with a density of $10.4 \mathrm{~g} / \mathrm{cm}^{3}$ stacked in type 6063 aluminum tubes that were $1.39 \mathrm{~cm}$ OD by $0.051 \mathrm{~cm}$ thick. Rod spacing was malntalned by small nylon rings at approximately $90 \mathrm{~cm}$ intervals along the rods. The rods consisted of a $91.6-\mathrm{cm}-$ long top section folned to a 183.1-cm-long bottom section by a 1.04-cm-Iong aluminum connector. The 19 rod clusters were enclosed in $12.7-\mathrm{cm}-O D$ by $0.145-\mathrm{cm}-$ thick housing tubes of type 6063 aluminum. The clusters were centered in the housing tubes by means of $0.159-\mathrm{cm}-\mathrm{th} 1 \mathrm{ck}$ spacers of type 1100 aluminum taped to the fuel assemblies near the bottom of the fuel assemblies and near the joint connecting the top and bottom rod sections. Calculations indicated that any changes in lattice buckling caused by these spacers or by the nylon-ring rod spacers were negligible. The housing tubes were provided with bottom plugs so that $D_{2} O$ could be admitted to, or excluded from, the fuel. Detalls of the fuel location in relation to the bottom of the PDP are shown in Figure 14. 
The fuel assemblies that were used in the SE were 1dentical to those used in the PDP except that they were $183.1 \mathrm{~cm}$ long, consisting of the bottom section of fuel rods only.

\section{BUCKLING MEASUREMENTS}

\section{PDP Buckling Measurements}

Radial and vertical buckling measurements were made in four of the PDP loadings by measuring flux profiles in the critical lattices. The flux profiles were obtained by actlvating gold pins, $1.27 \mathrm{~cm}$ long by $0.016 \mathrm{~cm}$ diameter, in a large number of interstitial positions throughout the lattice. The gold pins were supported on the light aluminum rods shown in Figure 14. For vertical flux traverses the gold pins were spaced $10 \mathrm{~cm}$ apart in at least four different locations in the lattice. Radial flux traverses were obtalned with at least 35 different radial locations using 3 different vertical levels at each location. A typical gold pin layout is shown in Figure 15.

In each irradiation run the critical moderator helght was measured relative to an arbitrary zero point to within $\pm 0.1 \mathrm{~cm}$ using a calibrated glass standplpe.

The 1rradiated gold pins were counted on NaI (TI) scintillation counters blased to reject gammas of less than $300 \mathrm{kev}$. The count rates were corrected according to standard methods for background, dead time of the counters, and decay. Each set of gold pins was counted at least four times. The corrected count rates were then least squares fitted to $J_{0}$ and cosine functions by an IBM 704 code, JOCOSE, to obtain the vertical and radial bucklings and their statistical errors. In the least squares fits, an attempt was made to eliminate errors due to boundary and reflector effects by running successive fits of the same sets of gold pin data and successively eliminating polnts from the extreme reglons of the lattice. In all cases, the resulting bucklings showed only slight random varlation as soon as the data taken near or at the extreme boundary were discarded. A typical vertical traverse is shown in F1gure 16 .

The combination of four or more countings of three or four traverses (radial and vertical, respectively) resulted In as many as 28 least squares fits in each loading. Except in cases where the counting was obviously bad due to instrument fallure, the least squares results were simply averaged to obtain the geometrical bucklings for the lattice. The 
averaged $B^{2}$ results for each lattice are given in Table III. The flag on these values represents the root mean square deviation of the several determinations in each lattice.

\section{TABLE III}

Results of Flux Mapping Irraoiations and Data Fitting in PDP Loadings

\begin{tabular}{|c|c|c|c|c|c|c|c|}
\hline \multirow{2}{*}{$\begin{array}{l}\text { Loading } \\
\text { No. } \\
\end{array}$} & \multirow{2}{*}{\multicolumn{2}{|c|}{$\begin{array}{c}\text { Fuel } \\
\text { Assemblies }\end{array}$}} & \multirow[b]{2}{*}{$\begin{array}{l}\text { No. of } \\
\text { Fittings }\end{array}$} & \multicolumn{4}{|c|}{ Fitting Results, $\mathrm{m}^{-2}$} \\
\hline & & & & \multicolumn{2}{|r|}{$\mathrm{B}_{2}{ }^{2}$} & \multicolumn{2}{|c|}{$\mathrm{B}_{r}{ }^{2}$} \\
\hline 1 & & 332 & $\begin{array}{l}28 \\
10\end{array}$ & $\begin{array}{l}2.361 \\
2.285\end{array}$ & $\begin{array}{l} \pm 0.011 \text { (Inner) }^{(a)} \\
\pm 0.013 \text { (outer) }^{(a)}\end{array}$ & 0.852 & $\begin{array}{l} \pm 0.008^{(b)} \\
-\end{array}$ \\
\hline 5 & 120 & reflected & $\begin{array}{l}15 \\
18\end{array}$ & 1.903 & $\begin{array}{l} \pm 0.011 \\
-\end{array}$ & 1.255 & $\begin{array}{l}- \\
\pm 0.008\end{array}$ \\
\hline 6 & 120 & $\begin{array}{l}\text { lithium } \\
\text { boundary }\end{array}$ & $\begin{array}{l}22 \\
11\end{array}$ & 1.226 & \pm 0.006 & 2.039 & $\begin{array}{l}- \\
\pm 0.011\end{array}$ \\
\hline 7 & & 156 & $\begin{array}{l}27 \\
21\end{array}$ & 1.516 & \pm 0.005 & 1.737 & $\begin{array}{l}- \\
\pm 0.008\end{array}$ \\
\hline
\end{tabular}

(a) Refers to vertical traverses taken over the baffle plate (inner) and away from the baffle plate (outer).

(b) The buckling result of the radial flux traverse in loading No. 1 was obtained from a one-region fit to a Jo flux shape. It was not used in the final analysis for this loading. See page 15.

A number of corrections were applied to the vertical bucklings obtained from the flux traverses to obtain the clean lattice bucklings. These corrections are discussed below. No corrections were applied to the measured radial bucklings.

1. A correction was made to account for the polsoning effect of the flux mapping gold pins and their holders. Th1s correction was determined experimentally by measuring the critical moderator height during the gold pin irradiation and again after the gold pin assemblies had been removed. The difference in moderator helght between the two conditions was obtained with a precision of $\pm 0.1 \mathrm{~cm}$. It was assumed, as had been done in earlier work $(6)$, that the difference between the extrapolated plle helght, $H$, and the measured moderator height, $S$, was independent of the presence of the gold flux mapping assemblies in a glven lattice. It was also assumed that the radial bucklings were unaffected by the gold. 
Using these assumptions the measured change in critical moderator helght obtalned upon removing the gold was converted to a buckling correction. The accuracy of $\pm 0.1 \mathrm{~cm}$ in measuring the moderator helght change corresponds to an uncertainty of $\pm 0.002 \mathrm{~m}^{-2}$ in buckling.

2. A correction was made to account for the presence of three alr-filled thimbles used in all loadings as guide tubes for two control rods and a source rod. Three additional tubes, Identical to the three already present, were inserted into the full loading (No. 1) in lattice positions equivalent to those of the first three tubes. The resulting change in buckling was used directly as the correction for this loading. The corrections for the rest of the loadings were calculated from the measured number for loading No. I using the relative statistical weights of the tubes in each loading. The corrections ranged from 0.003 to $0.006 \mathrm{~m}^{-2}$. An uncertainty of $\pm 0.001 \mathrm{~m}^{-2}$ was assigned to them.

3. The temperature and $D_{2} O$ purity changed slightly during the experiments necessitating small corrections to put all bucklings on the same basis. The temperature and $\mathrm{D}_{2} \mathrm{O}$ purity coefficlents of reactivity were calculated using the BSQ code $(7)$, an IBM 704 code routinely used at SRL to calculate heavy water lattices. The coefficlents were $0.01 \mathrm{~m}^{-2} /{ }^{\circ} \mathrm{C}$ and $0.62 \mathrm{~m}^{-2} / \% \mathrm{D}_{2} \mathrm{O}$, respectively. All buckling measurements were corrected to $20^{\circ} \mathrm{C}$ and $99.57 \mathrm{~mol} \% \mathrm{D}_{2} \mathrm{O}$. Temperature and $\mathrm{D}_{2} \mathrm{O}$ purity changes were measured with precisions of $\pm 0.003^{\circ} \mathrm{C}$ and $\pm 0.005 \%$ $\mathrm{D}_{2} \mathrm{O}$, respectively, so that the uncertainty on the correction factor is negligible. However, the absolute temperature uncertainty was about $\pm 0.5^{\circ}$ and the uncertainty in absolute $D_{2} \mathrm{O}$ purity was $\pm 0.02 \% \mathrm{D}_{2} \mathrm{O}$ resulting in absolute buckling uncertalnties of $\pm 0.005 \mathrm{~m}^{-2}$ and $\pm 0.012 \mathrm{~m}^{-2}$, respectively.

4. A final correction was applied to account for the decrease in buckling due to the gap in the fuel at the connection between the top and bottom fuel sections. This correction was obtalned by a flux measurement across the gap to determine the effect on $f$ and $L^{2}$ together with calculations to determine the effect on $p$. This calculation is fully described on page 36 . An uncertainty of $\pm 25 \%$ was assigned to this correction.

The corrections and the final bucklings for all loadings are summarized in Tabie IV. The uncertainties discussed above were statistically combined to give the flags for the first four loadings in Table IV. 
The bucklings for the last four loadings listed in Table IV were not measured by flux mapping, but were obtalned from the critical moderator helghts measured in these loadings. In each of the flux-mapped loadings (No. 1, 5, 6, and 7), $17.4 \mathrm{~cm}$ was the difference between the critical moderator helght, $S$, measured w1th the glass standp1pe, and the extrapolated pile helght, $\mathrm{H}$, obtained from the goldcount-rate data. This result confirms earlier indications $(6)$ that the quantity $H$ minus $S$ is independent of the pile helght for a glven lattice. The vertical bucklings for loadings No. $2,3,4$, and 8 in Table IV were therefore obtained simply by adding $17.4 \mathrm{~cm}$ to the measured moderator height to obtain the extrapolated pile helght.

The radlal bucklings for loadings No. 2 and 3 were assumed to remain unchanged from loading No. 1 because the only change made in the lattice was the addition of copper polson tubes. For loadings No. 4 and 8 in which no direct measure of the radial buckling was obtalned, use was made of the relationship

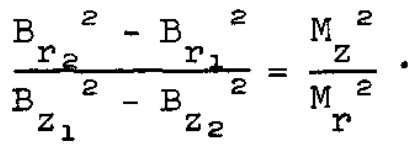

$\frac{\mathrm{M}_{2}{ }^{2}}{\mathrm{M}_{\mathrm{r}}{ }^{2}}$ is the latt1ce an1sotropy discussed on page 18, and

$\mathrm{B}_{\mathrm{r}_{1}}{ }^{2}, \mathrm{~B}_{\mathrm{Z}_{1}}{ }^{2}, \mathrm{~B}_{\mathrm{r}_{2}}{ }^{2}$, and $\mathrm{B}_{\mathrm{Z}_{2}}{ }^{2}$ refer to geometrical bucklings in

two differently shaped loadings (eg, different numbers of fuel assemblies) of the same lattice. Using the value 1.16 for the lattice an1sotropy (see page 19) together with the vertical bucklings discussed above, the radial bucklings given in Table IV for loadings No. 4 and 8 were computed by equation ( 1 ).

\section{TABLE IV}

Summary of Measured Bucklings and Corrections in PDP Loadings

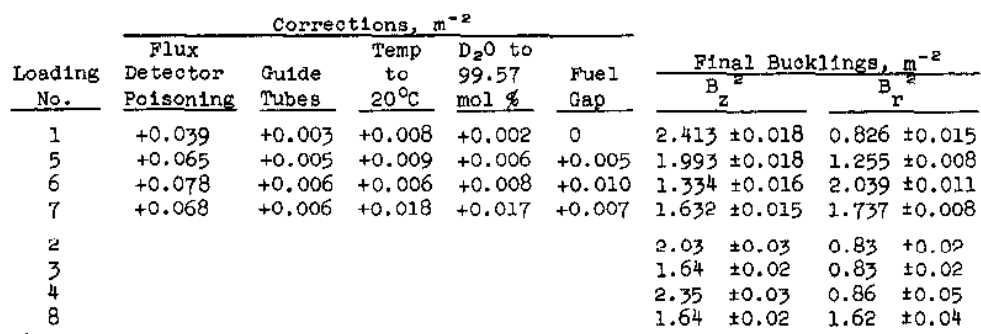


A unique situation was presented by the full pile loadings of 332 fuel assemblies which extended out beyond the moderator inlet baffle plate shown in Figure 15. This plate, which is 1.27 -cm-thick stalnless steel, is located $3.81 \mathrm{~cm}$ above the nominal tank bottom and effectively divides the pile into two radial regions with a small difference in vertical buckling between them. The effect is clearly shown in the vertical flux traverse results listed in Table $V$ for loading No. 1 .

To determine a more nearly correct lattice buckling for this loading, an IBM 704 code was written to make a least squares fit of the radial traverse data to a two region solution of the one group diffusion equation. The form to which the data were fitted was

$$
\begin{aligned}
& \Phi(r)=A_{0}\left(B_{r} r\right), r<R_{0} \\
& \Phi(r)=C J_{0}\left(B_{r}^{\prime} r\right)+C^{\prime} Y_{0}\left(B^{\prime} r\right), r>R_{0}
\end{aligned}
$$

where $R_{0}$ is the cylindricized radius of the baffle plate (108 cm) and $B_{r}$ and $A$ are the fltting parameters $\left(C\right.$ and $C^{\prime}$ are determined as functions of $A$ by continulty of flux and current at $R_{0}$ ).

Figure 17 shows the results of fltting the radial flux traverse data for loading No. I with various values of

$$
\Delta B_{r}^{2}=B_{r}^{2} \text { outer }-B_{r}^{2} \text { inner }
$$

To arrive at the proper value of $\Delta \mathrm{B}_{\mathrm{r}}{ }^{2}$, it was assumed that the difference in vertical buckling between the two reglons as measured in the vertical flux traverses was equal, after correction for anisotropy, to the difference in radial buckling in the two regions. The vertical buckling difference was measured as $0.078 \mathrm{~m}^{-2}$ (Table V) and the latt1ce anisotropy was determined as 1.16 (see page 19). Therefore, the $\Delta B_{r}{ }^{2}$ is $0.078 \times 1.16=0.09 \mathrm{~m}^{-2}$, and from Figure 17 the radial buckling of the inner region is $0.826 \mathrm{~m}^{-2}$. The required buckings are:

$$
\begin{aligned}
& \mathrm{B}_{\mathrm{r}}^{2}=0.826 \mathrm{~m}^{-2} \text { (1nner) } \\
& \mathrm{B}_{\mathrm{z}}^{2}=2.413 \mathrm{~m}^{-2} \text { (1nner) }
\end{aligned}
$$

These values are isted in Table IV. 
TABLE V

Vertical Flux Traverse Results in PDP Loading No. I

\begin{tabular}{|c|c|c|}
\hline \multirow[b]{2}{*}{ Traverse Rod $(a)$} & \multicolumn{2}{|c|}{ Fitting Results $\mathrm{B}_{\mathrm{z}}{ }^{2}, \mathrm{~m}^{-2}$} \\
\hline & $\begin{array}{l}\text { Individual Traverses, } \\
\text { Uncorrected Results }\end{array}$ & $\begin{array}{c}\text { Averaged } \\
\text { Corrected Results }\end{array}$ \\
\hline $\begin{array}{l}\text { Over } \\
\text { Baffle } \\
\text { Plate }\end{array}$ & $\begin{array}{l}2.364 \\
2.367 \\
2.345 \\
2.363\end{array}$ & 2.413 \\
\hline $\left.\begin{array}{l}\text { E } \\
\text { F }\end{array}\right\} \begin{array}{l}\text { Away from } \\
\text { Bafle Plate }\end{array}$ & $\left.\begin{array}{l}2.283 \\
2.286\end{array}\right\}$ & 2.335 \\
\hline
\end{tabular}

(a) Refers to vertical traverse rod locations in loading. See Figure 15.

\section{SE Buckling Measurements}

In the SE experiments, the vertical buckling, $\kappa_{z}{ }^{2}$, is determined from the vertical flux distribution as measured by a small, movable Ion chamber. Because there are fast neutrons leaking into the SE along with the thermal neutron source, and also because of the photoneutrons created by SP gamma rays reaching the $S E$, it is necessary to make a background flux determination w1th each measurement. The background run is made with a cadmlum sheet between the $S E$ and the SP. The net flux distribution - the difference between the total and background fluxes - is then fitted by the method of least squares to the function

$$
\Phi_{1}=A \sinh \kappa_{z}\left(x+\delta-z_{1}\right)
$$

where $\phi_{1}=$ the flux measured at some vertical position, $z_{1}$;

$$
\begin{aligned}
A= & \text { a constant; } \\
\kappa_{z}{ }^{2}= & \text { (vertical relaxation length) }{ }^{-2} ; \\
X= & \text { distance from the top surface of water to some } \\
& \text { zero polnt from which } Z_{1} \text { is measured; and } \\
\delta= & \text { vertical extrapolation length. }
\end{aligned}
$$

Inftialiy, the data are fitted to the above expression, assuming $A, \kappa_{z}$, and $\delta$ as unknown. The least squares fitting of the data 1 s not sensitive enough to allow the best values of all three parameters to be determined from each measurement; therefore, an average value of $\delta$ is determined from 
three parameter fits for all data on all lattlces; then the data are refitted to the parameters $A$ and $\kappa_{z}$.

For the SE lattice arrangements shown in F1gure 12, three different measurements of $\kappa_{z}{ }^{2}$ were made in the unpolsoned lattices - one measurement preceding the insertion of copper polson tubes in the lattice and two following the removal of the tubes. Each measurement cons1sted of from 4 to 8 separate traveling monitor traverses. Measurements with the poison tubes in place consisted of 10 and 4 determinations of $\mathrm{K}_{\mathrm{z}}{ }^{2}$ for the fuel-centered and moderator-centered lattices, respectively. The maximum spread in $\kappa_{z}{ }^{2}$ between the separate traverses in a single measurement was $\pm 0.02 \mathrm{~m}^{-2}$.

Using the calculated $\mathrm{D}_{2} \mathrm{O}$ purity coefficient of $0.62 \mathrm{~m}^{-2} /$ $\% \mathrm{D}_{2} \mathrm{O}$, the measured $\kappa_{\mathrm{z}}{ }^{2}$ values were corrected to a reference $\mathrm{D}_{2} \mathrm{O}$ purity of $99.57 \mathrm{~mol} \% \mathrm{D}_{2} \mathrm{O}$. Table VI lists the final $x_{z}{ }^{2}$ values obtained for the SE lattices.

TABLE VI

$\kappa_{z}{ }^{2}$ Measurements in the $\mathrm{SE}$

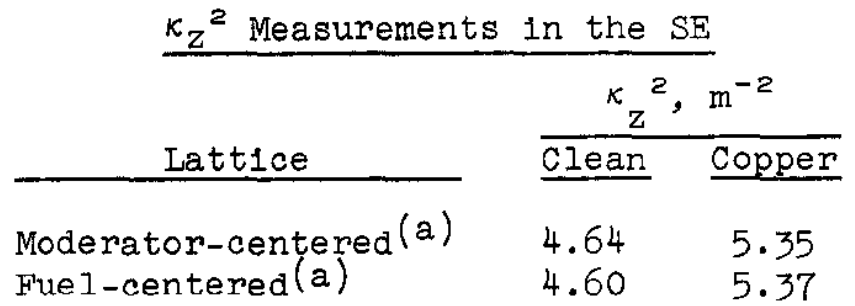

(a) Each point assigned an uncertainty of $\pm 0.03 \mathrm{~m}^{-2}$.

Radial buckling measurements were made in each of the lattice arrangements shown in Figure 12. Flve levels of gold pins, $7.6 \mathrm{~cm}$ apart, were placed in the positions ind1cated. For reasons discussed on page 16 , it was necessary to repeat each irradiation with the cadmium sheet between the SE and the SP. The net activities were fitted to the expression

$$
\Phi_{1}=\mathrm{AJ}_{0}\left(\mathrm{~B}_{\mathrm{r}} \mathrm{r}_{1}\right)
$$

Table VII 11sts, for each lattice arrangement, the resulting values of $\mathrm{Br}_{\mathrm{r}}{ }^{2}$, a mean value, and the standard deviation of the mean. 


\section{TABLE VII}

Radial Buckling Measurements in the SE

\begin{tabular}{|c|c|c|}
\hline \multirow[b]{2}{*}{ Leve1 } & \multicolumn{2}{|c|}{$\mathrm{B}_{\mathrm{r}}{ }^{2}, \mathrm{~m}^{-2}$} \\
\hline & Moderator-Centered & Fuel-Centered \\
\hline $\begin{array}{l}1 \text { (bottom) } \\
2 \\
3 \\
4 \\
5 \text { (top) }\end{array}$ & $\begin{array}{l}9.04 \\
9.01 \\
9.06 \\
9.10 \\
9.06\end{array}$ & $\begin{array}{l}8.96 \\
9.01 \\
8.91 \\
8.93 \\
8.88\end{array}$ \\
\hline Mean & $9.05 \pm 0.02$ & $8.94 \pm 0.03$ \\
\hline
\end{tabular}

Results of previous experiments lead to the belief that the true uncertainty is not represented by the standard deviations listed in the table and that $\pm 0.05 \mathrm{~m}^{-2}$ is more realistic. The difference measured between the two lattice loadings is real, because the fuel-centered lattice has a thicker reflector than the moderator-centered lattlce.

\section{ANISOTROPY DETERMINATION}

In reactor lattices that contain volds, the critical geometrical buckling, $\left(\mathrm{B}_{\mathrm{r}}{ }^{2}+\mathrm{B}_{\mathrm{z}}{ }^{2}\right)$, is not characterized by the lattlce parameters alone, but depends on the geometry of the system. Th1s results from the fact that the directional components of the migration area are unequal because of volds in the lattice. In one-group notation

$$
k_{\infty}-1=M_{r}{ }^{2} B_{r}^{2}+M_{z}{ }^{2} B_{z}^{2}
$$

wh1ch may be rewritten as

$$
\left(\mathrm{B}_{r}{ }^{2}+\mathrm{B}_{\mathrm{z}}{ }^{2}\right)=\frac{\mathrm{k}_{\infty}-1}{\mathrm{M}_{r}{ }^{2}}-\frac{\mathrm{M}_{\mathrm{z}}{ }^{2}-\mathrm{M}_{r}{ }^{2}}{\mathrm{M}_{r}{ }^{2}} \mathrm{~B}_{\mathrm{z}}{ }^{2}
$$

Therefore, the critical geometrical buckling, $\left(\mathrm{B}_{\mathrm{r}}{ }^{2}+\mathrm{B}_{\mathrm{z}}{ }^{2}\right)$, for any particular lattice shape, is a linear function of the vertical buckling. The anisotropy, $\mathrm{M}_{z}{ }^{2} / \mathrm{M}_{\mathrm{r}}{ }^{2}$, may be determined from critical buckling measurements made In at least two different geometrical shapes by determining the slope, $\left(\mathrm{M}_{\mathrm{z}}{ }^{2}-\mathrm{M}_{\mathrm{r}}{ }^{2}\right) / \mathrm{M}_{\mathrm{r}}{ }^{2}$, of the line passing through a plot of $\left(B_{r}{ }^{2}+B_{z}{ }^{2}\right)$ versus $B_{z}{ }^{2}$.

In the present experiment, cores of flve different shapes were used, including the subcritical cores in the SE. These cores were loading No. 1,6 , and 7 in the PDP and the two SE loadings. 
The buckling results for these lattices are plotted in F1gure 18. Only reduced cores with a "polsoned" reflector and full pile loadings were used in establishing the slope of the line. The least squares fit to the data using both $\mathrm{SE}$ and PDP points ylelds

$\frac{\mathrm{M}_{\mathrm{Z}}{ }^{2}-\mathrm{M}_{\mathrm{r}}{ }^{2}}{\mathrm{M}_{\mathrm{r}}{ }^{2}}=0.16$ or, $\frac{\mathrm{M}^{2}}{\mathrm{M}_{\mathrm{r}}^{2}}=1.16 \pm 0.01$.

Using only the PDP data points ylelds $1.13 \pm 0.03$ for the anisotropy. The uncertainty indicated for these two values represents the standard deviation of the least squares fit of the experimental points (five and three points, respectively).

The theory of Beno1st $(8,9)$ was used to obtain a theoretical value of the anisotropy. The two group parameters used as input in the calculation are given in Table VIII. The calculation gave a value of 1.17 for $\mathrm{M}_{z}{ }^{2} / \mathrm{M}_{\mathrm{r}}{ }^{2}$, in very good agreement w1th the measured result.

\section{TABIE VIII}

Input Parameters for Calculation of Migration Area Anisotropy

\begin{tabular}{|c|c|}
\hline Parameter & Value \\
\hline $\begin{array}{l}\text { Average thermal flux in moderator region } \\
\text { (arb1trary units) }\end{array}$ & 134.08 \\
\hline Average thermal flux in ruel region & 87.40 \\
\hline Cuter radius of fuel, cm & 3.761 \\
\hline Cuter radius of vold region, $\mathrm{cm}$ & 6.35 \\
\hline Lattice pltch, cm & 23.09 \\
\hline $\begin{array}{l}\text { Thermal transport mean free path in } \\
\text { moderator reglon, } \mathrm{cm}\end{array}$ & 2.478 \\
\hline $\begin{array}{l}\text { Thermal transport mean free path in fuel } \\
\text { regions, cm }\end{array}$ & 4.735 \\
\hline $\begin{array}{l}\text { Fast transport mean free path in moderator } \\
\text { regions, cm }\end{array}$ & 3.46 \\
\hline $\begin{array}{l}\text { Fast transport mean free path in fuel } \\
\text { region, cm }\end{array}$ & 5.085 \\
\hline $\begin{array}{l}\text { Rat1o of thermal flux at fuel surf'ace to } \\
\text { average flux in fuel(a) }\end{array}$ & 1.170 \\
\hline $\begin{array}{l}\text { Thermal macroscopic absorption cross } \\
\text { sections in fuel region }(a), \mathrm{cm}^{-1}\end{array}$ & 0.0835 \\
\hline Ferm1 age for moderator $\left(99.6 \mathrm{~mol} \% \mathrm{D}_{2} \mathrm{O}\right), \mathrm{cm}^{2}$ & 128.4 \\
\hline $\begin{array}{l}\text { Effective thermal, macroscopic absorption } \\
\text { cross sectlons in cell, } \mathrm{cm}^{-1} \text {. }\end{array}$ & 0.0552 \\
\hline $\begin{array}{l}\text { TOTE: Thermal oross sections and flux ratios } \\
\text { were obtained from THERMOS calculations }\end{array}$ & \\
\hline
\end{tabular}

(a) These parameters were used to calculate the average thermal flux in the vold region. 


\section{VERTICAL MIGRATION AREA}

\section{Copper Poison Method}

One method of determining the migration area of a lattice is to add a known amount of absorber uniformly to the lattice (thereby introducing a change in $k_{\infty}$ ) and then measure the resulting change in critical buckling. If the two-group, anisotropic form of the critical equation is used,

$$
\mathrm{k}_{\infty}=\eta \in \mathrm{pf}=\left(1+\mathrm{L}_{\mathrm{r}}{ }^{2} \mathrm{~B}_{\mathrm{r}}{ }^{2}+\mathrm{L}_{\mathrm{z}}{ }^{2} \mathrm{~B}_{\mathrm{z}}{ }^{2}\right)\left(1+\tau_{\mathrm{r}} \mathrm{B}_{\mathrm{r}}{ }^{2}+\tau_{z_{z}}{ }^{2}\right)
$$

It can be shown that

$$
\begin{aligned}
& \left(L_{z}{ }^{2}+\tau_{z}\right)=\frac{\frac{\Delta f}{f}\left[I+L_{z}{ }^{2}\left(G B_{r}{ }^{2}+B_{z}{ }^{2}+\Delta B_{z}{ }^{2}\right)-2 L_{z}{ }^{2} \tau z^{\Delta B}{ }^{2}\left(G B_{r}{ }^{2}+\Delta B_{z}{ }^{2}\right)\right]}{\Delta B_{z}{ }^{2}-\left(G B_{r}{ }^{2}+B_{z}{ }^{2}\right)\left(\frac{\Delta f}{f}+\frac{\Delta p}{p}\right)} \\
& +\frac{\frac{\Delta p}{p}\left[I+L_{z}{ }^{2} \tau_{z}\left(G B_{r}{ }^{2}+B_{z}{ }^{2}\right)^{2}\right]-L_{z}{ }^{2} \tau_{z}\left[\left(2 G B_{r}{ }^{2}+B_{z}{ }^{2}\right) \Delta B_{z}{ }^{2}+\left(\Delta B_{z}{ }^{2}\right)^{2}\right]}{\Delta B_{z}{ }^{2}-\left(G B_{r}{ }^{2}+B_{z}{ }^{2}\right)\left(\frac{\Delta f}{f}+\frac{\Delta p}{p}\right)}
\end{aligned}
$$

It is here assumed that the only terms affected by the addition of the absorber are $f$, the thermal utilization; $p$, the resonance escape probability; and $L^{2}$, the thermal diffusion area. All of the terms in (9) have their standard definitions except for $G$, which is equal to $\mathrm{M}_{\mathrm{r}}{ }^{2} / \mathrm{M}_{\mathrm{z}}{ }^{2}$, and which was inserted to allow $\tau_{r}$ and $L_{r}{ }^{2}$ to be expressed in terms of $\tau_{\mathrm{z}}$ and $\mathrm{L}_{\mathrm{z}}{ }^{2}$, respectively. Assuming that $\tau$ and $\mathrm{L}^{2}$ have the same $G$ term has negligible affect on the results.

In the present experiments, the absorbing poison was copper tubes, $1.588 \mathrm{~cm}$ outside diameter with a $0.069 \mathrm{~cm}$ nominal wall thickness. These tubes were added to several lattices and the resulting changes in vertical buckling, $\mathrm{B}_{\mathrm{z}}{ }^{2}$, were measured. These lattices were: (I) 332 fuel assemblies, PDP, copper in altemate positions in the pile, F1gure 3; (2) 332 fuel assemblies, PDP, copper in all possible positions, Flgure 4; (3) 32 assemblies, SE, copper In all possible positions, F1gure 12B; and (4) 29 assemblies, SE, copper in all possible positions, Figure 12A. The copper tubes were placed at the corners of the square lattice cells. The dimensions of 50 of the 300 copper tubes were measured; cross-sectional area varled by no more than about $\pm 1 \%$, from an average value of $0.3265 \mathrm{~cm}^{2}$. Chem1cal and spectrographic analyses of a representative sample of the copper revealed no appreciable quantities of other absorbing materials. 
The absorption ratio between the copper tubes and the fuel was measured in lattlces (1) and (2) above, and later in a special loading in which the center 40 positions of a 156-assembly pile in the PDP contalned copper tubes. Machined copper folls, $1.27 \mathrm{~cm}$ in diameter and $0.015 \mathrm{~cm}$ thlck, were placed between fuel pellets in each of the four rod symmetry types in the test fuel assembiles. In each irradiation, four vertical levels of bare folls and one level of cadmium-covered folls were used. Fo1ls $1.27 \mathrm{~cm}$ in diameter and $0.015 \mathrm{~cm}$ thick were cut from two of the copper tubes at levels corresponding to the measurement levels in the fuel. Epicadmium activities in the copper tubes were determined by placing copper strips, $1.27 \mathrm{~cm}$ long, $0.015 \mathrm{~cm}$ thick, and $0.15 \mathrm{~cm}$ wide, in 0.076 -cm-thick cadmium wrappers at the surface of the copper tubes. All folls were counted several times with scintiliation counters. Folls were cal1brated by irradiation in a uniform thermal flux.

The ratios of the average neutron density in the copper tubes to the average neutron density in the fuel obtained from the corrected foll count rates in each lattice are given in Table IX. The headings $\mathrm{Cu}_{1}$ and $\mathrm{Cu}_{2}$ refer to the two copper tubes from whlch folls were cut following the irradiation.

\section{TABIE IX}

Rat1o of Average Neutron Density in Copper Tubes to Average Neutron Density in Fuel, as Measured by Copper Folls

\begin{tabular}{|c|c|c|}
\hline Loading & $\overline{\mathrm{n}}_{\mathrm{Cu}_{2} / \overline{\mathrm{n}}_{\mathrm{U}}}$ & $\overline{\mathrm{n}}_{\mathrm{Cu}}$ \\
\hline $1 / 2$ copper loading, lattice (1) & 1.757 & 1.732 \\
\hline Full copper loading, lattlce (2) & $1.667^{(a)}$ & 1.766 \\
\hline Special loading & 1.749 & 1.74 \\
\hline
\end{tabular}

Average and standard deviation of average

$1.751 \pm 0.005$

(a) The value of 1.667 was omitted from the average since it differs from the mean by more than 30 .

The ratio of absorptions within one fuel assembly to absorptions within one copper tube is obtained from the above ratios by: 


$$
\frac{\left(\Sigma_{a} \phi V\right)_{C u}}{\left(\Sigma_{a} \phi V\right)_{U}}=\frac{(\bar{v} \bar{\Sigma} a \bar{n} V)_{C u}}{\left(\bar{v} \bar{\Sigma} \bar{a}^{\bar{n} V}\right)_{U}}=\frac{\bar{n}_{C u}}{\overline{\bar{n}}_{U}} \cdot \frac{V_{C u}}{V_{U}} \cdot \frac{\left(\bar{v} \bar{\Sigma}_{a}\right)_{C u}}{\left(\bar{v} \bar{\Sigma}_{a}\right)_{U}}
$$

The ratio of the effective cross sections times the average velocity within the fuel was determined from a THERMOS(11) calculation to be 1.8716 . Assuming the uranium oxide rods to be exactly $1.27 \mathrm{~cm}$ in dlameter, the volume rat10 was determined from measured welghts of the copper tubes to be $0.01356 \pm 1 \%$. Thus, the absorption rat10 between fuel and copper tubes is

$$
\frac{\left(\Sigma_{a} \phi V\right)_{C u}}{\left(\Sigma_{a} \phi V\right)_{U}}=(1.751)(1.8716)(0.01356)=0.04445
$$

In a finite lattice there are unequal numbers of fuel assemblies and copper tubes and they are not in a flat flux; therefore $1 t$ is necessary to flux-welght the copper and fuel absorptions. The flux-welghting ratio, designated $Q$, is given by

$$
Q=\frac{\sum_{I} N_{1} J_{0}\left(B r_{1}\right)}{\sum_{j} N_{j} J_{0}\left(B r_{j}\right)}
$$

where the subscript 1 refers to copper tubes and $j$ to fuel assemblies.

The flux welghtings for each of the lattices measured are given in Table $x$.

\begin{tabular}{|c|c|}
\hline Latt1ce & $Q$ \\
\hline $\begin{array}{l}\text { SE, moderator-centered } \\
\text { SE, fuel-centered } \\
\text { PDP, l/2 copper loading } \\
\text { PDP, full copper loadling }\end{array}$ & $\begin{array}{l}0.8515 \\
0.9363 \\
0.4704 \\
0.9301\end{array}$ \\
\hline
\end{tabular}

\section{TABLE X}

Flux-Welghting Copper Tubes and Fuel Assemblies

In equation (9) the measured quantities are $\Delta f / f, B_{r}{ }^{2}$, $\mathrm{B}_{\mathrm{z}}{ }^{2}, \Delta \mathrm{B}_{\mathrm{z}}{ }^{2}$, and $\mathrm{G}$. The remaining quantities are calculated. The procedures for measuring $\mathrm{B}_{\mathrm{r}}{ }^{2}, \mathrm{~B}_{\mathrm{z}}{ }^{2}, \Delta \mathrm{B}_{\mathrm{z}}{ }^{2}$, and $\mathrm{G}$ were described previously in this report. The method of obtaining $\Delta \mathrm{f} / \mathrm{f}$ from the measured copper absorptions and the method for calculating $\Delta \mathrm{p} / \mathrm{p}$ are in the following sections, along with the final $\left(L_{z}{ }^{2}+\tau_{z}\right)$ values. 
For purposes of development, define

$f=$ thermal utilization, Infinite lattice, no poison

$\mathrm{f}^{\prime}=$ thermal ut1lization, infinite lattice, poisoned

$f^{\prime \prime}=$ thermal ut1lization, finite lattice, polsoned

then,

$$
\frac{l}{f}=\frac{\text { absorptions in cell }}{\text { absorptions in fuel }}
$$

$\frac{1}{f^{\prime}}=\frac{1}{f}+\left(\frac{\text { absorptions in } 1 \text { poison tube }}{\text { absorptions in } 1 \text { fuel assembly }}\right)_{\text {flat } \phi} \cdot R$

where $R=\left(\frac{\text { number of polson tubes }}{\text { number of fuel assemblies }}\right)_{\text {infinite lattice }}$

$$
\frac{I}{f^{\prime \prime}}=\frac{1}{f^{\prime}}(Q)
$$

where $Q$ is the flux-weighting ratio of the poison tube positions with respect to the fuel positions given in Table $\mathrm{X}$.

Essentially, the $\Delta f / f$ determination consists of evaluating equation (15) using a calculated value of $f$.

Using equation (14), equation (15) may be written:

$$
\frac{1}{f^{\prime \prime}}=\frac{1}{f}+\frac{(\phi \Sigma V V)}{(\phi \Sigma V u}(Q)
$$

This equation is then used to determine $f^{\prime \prime}$. The evaluations of (15a) are given in Table XI together with the resulting values of $\Delta f / f$.

\begin{tabular}{|c|c|c|}
\hline Latt: & $f^{\prime \prime}$ & $\Delta f / f$ \\
\hline $\mathrm{SE}, \bmod$ & 0.91233 & 0.03 \\
\hline SE, fuel-centered & .90917 & .03777 \\
\hline PDP, $1 / 2$ copper poison & .92661 & .01932 \\
\hline PDP, full copper polson & 0.90942 & 0.03751 \\
\hline
\end{tabular}

\section{TABLE XI}

\section{$\Delta f / f$ due to Addition of Copper Tubes to Latt1ce}


The resonance neutron capture in the lattice containing copper tubes is increased by the resonance capture in $\mathrm{Cu}^{63}$ and $\mathrm{Cu}^{65}$ and by the eplcadmium $\mathrm{I} / \mathrm{v}$ absorptions. The equations for resonance capture can be approximated by

$$
\begin{aligned}
& \text { Resonance capture }=(1-p)=\frac{N_{U}}{\xi \Sigma_{s}^{D_{2} O}} \frac{V_{U}}{V_{m}} R I^{U} \\
& \left(1-p^{\prime}\right)=(1-p)+\frac{{ }_{C u}}{\xi \Sigma_{s}^{D_{2} O}} \frac{V_{C u}}{V_{m}}\left[\chi R I^{C u^{63}}+(1-\chi) R I^{C u^{65}}+\sigma_{I / v}^{C u}\right] \\
& \left(p^{\prime \prime}-p\right)=-\frac{N_{C u}}{\xi \Sigma^{D_{2} O}} \frac{V_{C u}}{V_{m}}\left[\chi R I^{C u^{63}}+(1-\chi) R I^{C u^{65}}+\sigma_{I / v}^{C u}\right] \text { (Q) }
\end{aligned}
$$

where $\quad N=$ number of atoms per unit volume

$$
\begin{aligned}
\xi \Sigma_{\mathrm{S}}^{\mathrm{D}_{2} \mathrm{O}}= & \text { slowing down power of moderator } \\
\chi= & \text { 1sotopic abundance of } \mathrm{Cu}^{63} \\
(1-\chi)= & \text { isotop1c abundance of } \mathrm{Cu}^{65} \\
\mathrm{RI}= & \text { resonance integral } \\
\mathrm{Q}= & \text { flux-weighting ratio polson positions with } \\
& \text { respect to fuel positions defined previously. }
\end{aligned}
$$

Then,

$$
\frac{\Delta p}{p}=\frac{p^{\prime \prime}-p}{p}
$$

In equations (16) through (20), the primes have the same definitions as those used in discussing $\Delta \mathrm{f} / \mathrm{f}$.

Values of $\Delta p / p$ were calculated using equations (19) and (20), together with the welghting terms given in Table $\mathrm{X}$ and the following parameters. 


$$
\begin{aligned}
\xi \Sigma_{\mathrm{s}}^{\mathrm{D}_{2} \mathrm{O}} & =0.186 \mathrm{~cm}^{-1} \\
\frac{\mathrm{V}_{\mathrm{Cu}}}{\mathrm{V}_{\mathrm{U}}} & =8.033 \times 10^{-4} \\
\mathrm{RI}^{\mathrm{Cu}} & =1.4 \text { barns (for } 0.069 \mathrm{~cm} \text { thickness) (12) } \\
\mathrm{RI}^{\mathrm{Cu}}{ }^{65} & =1.1 \text { barns } \\
\sigma_{1 / \mathrm{V}}^{C u} & =1.83 \text { barns } \\
\frac{\Delta \mathrm{p}}{\mathrm{p}} & =\left(1.52 \times 10^{-3}\right)(\mathrm{Q})
\end{aligned}
$$

The values of $\Delta \mathrm{p} / \mathrm{p}$ for each lattice are listed in Table XII.

\section{Results}

\begin{tabular}{|c|c|c|c|c|c|c|}
\hline Lattice & $\Delta f / f^{(b)}$ & $\Delta \mathrm{p} / \mathrm{p}^{(\mathrm{c})}$ & $\begin{array}{l}B_{r}^{2}, \\
m^{-2}\end{array}$ & $\mathrm{~B}_{\mathrm{m}^{-2}}^{2(\mathrm{a})}$, & $\begin{array}{l}\mathrm{B}^{2}{ }^{2}, \\
\mathrm{~m}^{-2}\end{array}$ & $\begin{array}{c}\left(\mathrm{L}_{\mathrm{z}}{ }^{2}+\tau_{\mathrm{z}}\right), \\
\mathrm{cm}^{2}\end{array}$ \\
\hline $\begin{array}{l}\text { SE, mod-cen } \\
\text { SE, fuel-cen } \\
\text { PDP, } 1 / 2 \mathrm{Cu} \\
\text { PDP, full } \mathrm{Cu}\end{array}$ & $\begin{array}{l}3.443 \\
3.777 \\
1.932 \\
3.751\end{array}$ & $\begin{array}{l}1.29 \\
1.42 \\
0.72 \\
1.41\end{array}$ & $\begin{array}{l}9.05 \\
8.94 \\
0.83 \\
0.83\end{array}$ & $\begin{array}{r}-4.64 \\
-4.60 \\
2.41 \\
2.41\end{array}$ & $\begin{array}{l}0.71 \\
0.77 \\
0.382 \\
0.770\end{array}$ & $\begin{array}{l}474 \pm 30 \\
481 \pm 30 \\
510 \pm 15 \\
476 \pm 11\end{array}$ \\
\hline & & & & & rerage & $483 \pm 14$ \\
\hline
\end{tabular}

The parameters used to evaluate equation (9) for $\left(L_{z}{ }^{2}-\tau_{z}\right)$ are summarized in Table XII together with the resulting values of $\mathrm{M}_{\mathrm{z}}{ }^{2}$.

\section{TABLE XII}

\section{$\left(L_{z}{ }^{2}+\tau_{z}\right)$ from Copper Poisoning Method}

(a) Clean buckling, no copper.

(b) Multiply $\times 10^{-2}$.

(c) Multiply $\times 10^{-3}$.

The other quantities needed to evaluate equation (9) are the value of $G=M_{r}{ }^{2} / M_{z}{ }^{2}$, which was taken from the experiments as $1 / 1.16$, and trial values of $\mathrm{L}_{z}{ }^{2}$ and $\tau_{z}$. These latter quantities were obtalned from Beno1st-type calculations $(8,9)$, using the data listed in Table VIII. The calculations gave $\mathrm{I}_{z}{ }^{2}=286.4 \mathrm{~cm}^{2}$ and $\tau_{z}=240.7 \mathrm{~cm}^{2}$. 
Iterating new values of $\mathrm{L}_{z}{ }^{2}$ and $\tau_{z}$ into equation (9) had negligible effect on the results.

The errors indicated on each value of $\mathrm{M}_{\mathrm{Z}}{ }^{2}$ in Table XII represent the experimental errors in $\Delta \mathrm{f} / \mathrm{f}$ and in $\Delta \mathrm{B}_{\mathrm{z}}{ }^{2}$. The standard deviation of $\pm 0.3 \%$ in the measured absorption ratio propagates through to $\Delta \mathrm{f} / \mathrm{f} . \Delta \mathrm{B}^{2}$ was measured to $\pm 0.005 \mathrm{~m}^{-2}$ In the PDP or to $\pm 1.5 \%$ in the $1 / 2$ copper loading and to $\pm 0.7 \%$ In the full copper loading. In the $\mathrm{SE}, \mathrm{B}_{\mathrm{z}}{ }^{2}$ can be measured to $\pm 0.02 \mathrm{~m}^{-2}$ so that the error in $\Delta \mathrm{B}_{\mathrm{z}}{ }^{2}= \pm 0.03 \mathrm{~m}^{-2}$ or $\pm 4.0 \%$. Another source of systematic error in $\left(\mathrm{I}_{z}{ }^{2}+\tau_{z}\right)$ comes from the uncertainty of approximately $\pm 1 \%$ in the ratio of absorption cross sections for copper and uranlum. This $\pm 1 \%$ uncertainty propagates through $\Delta \mathrm{f} / \mathrm{f}$ to $\left(\mathrm{I}_{\mathrm{z}}{ }^{2}+\tau_{\mathrm{z}}\right)$ as a $\pm 5 \mathrm{~cm}^{2}$ systematic error in all measurements. The average value of $483 \pm 14 \mathrm{~cm}^{2}$ Includes all sources of uncertainty listed above.

\section{Period Method}

A second 1ndependent determination of the migration area of the EL-4 mockup lattice was obtained by period measurements. In this method, the vertical geometrical buckling of the critical lattice is decreased a known amount and the resulting positive period is measured. A calculated period reactivity relationship is then used to obtain $\Delta k_{e f f}$. By means of two group theory $\left(\mathrm{L}_{z}{ }^{2}+\tau_{z}\right)$ is then calculated from the values of $\Delta k_{e f f} / \Delta B_{z}{ }^{2}$.

The first step in the experimental procedure was to reach a stable pile power and measure the critical moderator height of the clean lattice with no control rods present. At this stage the absolute pile power was relatively low ( 50 watts), but the signal from the flux measuring instruments was about 3 orders of magnitude above that at initial startup. The moderator height was then slowly increased by some predetermined amount, usually about $1 \frac{1}{2}$ to $2 \mathrm{~cm}$, while the pile power was held constant by inserting control rods. The new moderator height was measured. Next the control rods were rapidly driven out of the pile with the moderator height held constant. During the increase in pile power the flux level was monitored by four to $\mathrm{s} 1 \mathrm{x}$ compensated 1on chambers and two $\mathrm{BF}_{3}$ counting systems. The currents from the compensated ion chambers were recorded on strip-chart recorders as a function of time, and the $\mathrm{BF}_{3}$ counts were tabulated at fixed time intervals. The pile power was allowed to increase two or three orders of magnitude at which time the power was leveled off by dropping moderator back to 1 ts initial height. After about 20 minutes of constant power operation at the higher level, the moderator helght was again measured and the pile shut down. 
Period measurements were made six times in each of two different loadings, a total of twelve critical runs. The difference in moderator helght between the critical and supercritical conditions, and the plle period was obtained from each measurement.

The moderator helght difference, $\Delta H$, was measured with an electrical probe capable of determining relative water helghts with a precision of $\pm 0.005 \mathrm{~cm}$. The critical moderator heights determined at the higher power level were used in the calculations thus ensuring that any photoneutrons resulting from gamma activity from previous runs would be negligible In comparison to the fission neutrons. From the measured $\Delta H$ value the change in vertical buckling was calculated for each run.

The pile period for each run was calculated usling the flux data obtained from the compensated ion chambers and $\mathrm{BF}_{3}$ counting systems. The flux data during the initial part of the flux rise were not used in calculating the period; the walting period was calculated to allow the plle perlod to reach 1 ts asymptotic value within $1 \%$.

The measured $\Delta \mathrm{H}$ values and doubling times, along with the calcuiated $\Delta \mathrm{B}_{\mathrm{Z}}{ }^{2}$ values, are given in Table XIII. The uncertainties on the doubling times are the root-mean-square deviations obtalred from the several instruments in each run. The nominal uncertainty in subsequent calculations is taken as \pm 1 sec. The uncertainties in $\Delta B_{z}{ }^{2}$ result from the allowances of $\pm 0.01 \mathrm{~cm}$ in the measured $\Delta H$ and of \pm 0.2 to $0.5 \mathrm{~cm}$ in the absolute pile heights.

Values of $\Delta \mathrm{k}_{\mathrm{eff}}$ corresponding to the measured periods were obtalned from a calculated period reactivity relationsh1p. The delayed neutron and photoneutron groups were based on the neutron data given by Keepin(13).

Other constants used in the calculation were the average numbers of neutrons per fission $v^{28}=2.80, v^{25}=2.42$, and the neutron lifetime, $l=3.3 \times 10^{-4} \mathrm{sec}$. Two additional parameters used in the calculations were $\delta$, the ratio of $\mathrm{U}^{238}$ to $\mathrm{U}^{235}$ f'issions; and $\mathrm{T}$, the fraction of high energy gamma rays escaping capture or degradation in the fuel. These parameters depend upon the fuel assembly only and were calculated for this experiment as $\delta=0.0427$ and $T=0.39$. It is quite possible that the value of $\delta$ used in this calculation was in error by 5 to $10 \%$. The value of $T$ possibly was in error by as much as $10 \%$. The sensitivity of the results to changes in these parameters is given in Tabie XIV. 
The calculated values of $\Delta \mathrm{k}_{\text {eff }}$ are given in Table XIII. Also given in this table is the quantity $\left(\Delta \mathrm{k}_{e f f} /-\Delta \mathrm{B}_{z}{ }^{2}\right.$ ), which should be a constant for this experiment.

\section{TABIE XIII}

\section{Period Measurements in PDP}

\begin{tabular}{|c|c|c|c|c|c|c|c|c|}
\hline $\begin{array}{l}\text { oading } \\
\text { No. }\end{array}$ & $\underline{\text { Run }}$ & $\Delta \mathrm{H}$, & $\mathrm{cm}$ & $-\Delta B_{z}$ & a), $\mu \mathrm{B}$ & $\begin{array}{l}\text { Doubling } \\
\text { Time, } \\
\text { sec. }\end{array}$ & $\Delta k_{\text {eff }}$ & $\begin{array}{l}\frac{\Delta k_{e f f}}{-\Delta B_{z}^{2}} \\
\mathrm{~cm}^{2} \\
\end{array}$ \\
\hline 6 & $\begin{array}{l}1 \\
2 \\
3 \\
4 \\
5 \\
6\end{array}$ & $\begin{array}{l}1.478 \\
1.549 \\
1.770 \\
1.829 \\
1.948 \\
2.101\end{array}$ & $\begin{array}{l} \pm 0.01 \\
\pm 0.01 \\
\pm 0.01 \\
\pm 0.01 \\
\pm 0.01 \\
\pm 0.01\end{array}$ & $\begin{array}{l}1.370 \\
1.435 \\
1.633 \\
1.688 \\
1.795 \\
1.936\end{array}$ & $\begin{array}{l} \pm 0.009 \\
\pm 0.009 \\
\pm 0.009 \\
\pm 0.009 \\
\pm 0.010 \\
\pm 0.010\end{array}$ & $\begin{array}{l}86.5 \pm 1.1 \\
82.5 \pm 1.3 \\
67.6 \pm 0.9 \\
64.4 \pm 1.0 \\
59.4 \pm 0.5 \\
53.5 \pm 0.5\end{array}$ & & $\begin{array}{l}461.2 \\
454.7 \\
463.9 \\
465.2 \\
464.4 \\
463.8\end{array}$ \\
\hline 7 & $\begin{array}{r}7 \\
8 \\
9 \\
10 \\
11\end{array}$ & $\begin{array}{l}1.128 \\
1.229 \\
1.262 \\
1.346 \\
1.407 \\
1.748\end{array}$ & $\begin{array}{l} \pm 0.01 \\
\pm 0.01 \\
\pm 0.01 \\
\pm 0.01 \\
\pm 0.01\end{array}$ & $\begin{array}{l}1.314 \\
1.533 \\
1.573 \\
1.677 \\
1.751 \\
2.105\end{array}$ & $\begin{array}{l} \pm 0.020 \\
\pm 0.020 \\
\pm 0.021 \\
\pm 0.022 \\
\pm 0.022 \\
\pm 0.023\end{array}$ & $\begin{array}{l}89.0 \pm 0.9 \\
74.5 \pm 0.5 \\
72.2 \pm 0.5 \\
66.8 \pm 1.5 \\
62.3 \pm 0.6 \\
47.2 \pm 0.9\end{array}$ & $\begin{array}{l}7.041 \\
7.209 \\
7.633 \\
8.049 \\
9.791\end{array}$ & $\begin{array}{l}470.4 \\
459.2 \\
458.2 \\
455.1 \\
459.7 \\
465.1\end{array}$ \\
\hline
\end{tabular}

(a) $\mu \mathrm{B}=10^{-6} \mathrm{~cm}^{-2}$.

TABLE XIV

Sensitivity of $\Delta k_{\text {eff }} /-\Delta B_{z}{ }^{2}$ to Changes in $\delta$ and $T$

Change in $\Delta \mathrm{k}_{\text {eff }} /-\Delta \mathrm{B}_{\mathrm{z}}{ }^{2}$ per 0.004 increase in $\delta:=+1.6 \mathrm{~cm}^{2}$.

Change in $\Delta \mathrm{k}_{\text {eff }} /-\Delta \mathrm{B}_{\mathrm{z}}{ }^{2}$ per 0.01 increase in $\mathrm{T}=+1.5 \mathrm{~cm}^{2}$.

The vertical migration area was calculated using anisotrop 1c two-group theory in the form:

$$
\left(L_{z}{ }^{2}+\tau_{z}\right)=\frac{y-2 L_{z}{ }^{2} \tau_{z}\left(B_{r}{ }^{2}+B_{z}{ }^{2}\right)+y L_{z}{ }^{2} \tau_{z}\left(B_{r}{ }^{2}+B_{z}{ }^{2}\right)^{2}-x}{1-y\left(B_{r}{ }^{2}+B_{z}{ }^{2}\right)}
$$

where $\mathrm{x}$ is a correction for anisotropy given by

$$
x=B_{r}{ }^{2}\left[\left(L_{z}{ }^{2}-I_{r}{ }^{2}\right)\left(y-\tau_{z}\right)+\left(\tau_{z}-\tau_{r}\right)\left(y-L_{z}{ }^{2}\right)\right]
$$

and

$$
y=\Delta k_{e f f} /-\Delta B_{z}{ }^{2}
$$


Because $\mathrm{I}_{z}{ }^{2}, \mathrm{I}_{\mathrm{r}}{ }^{2}, \tau_{z}$, and $\tau_{r}$ appear only in second order terms on the right hand side of equation (21), calculated values of these quantities are sufficiently accurate. All quantities used in this calculation are listed in Table XV. The an1sotropy term, $x$, was taken as 1.16 , the result of the anisotropy measurement discussed previously in this report.

The resulting values of $\left(\mathrm{L}_{z}{ }^{2}+\tau_{z}\right)$ are given in Table XVI. The flags on the individual measurements represent a statistical combination of the experimental uncertainties only ( $1 e$, the uncertalnties in measuring $\Delta H$ and doubling times), and do not include the systemat1c error due to the uncertainty in the calculated values of $\delta$ and $T$. The flag on the we1ghted mean at the bottom of the table includes the experimental uncertainties plus the systematic uncertainties.

The mean value of $492 \pm 11 \mathrm{~cm}^{2}$ compares very favorably with the value of $483 \pm 14 \mathrm{~cm}^{2}$ obtained by the copper poison method discussed in the previous section.

A calculation based on Benolst $(8,9)$ using the input parameters given in Table VIII gives a value for $M_{z}{ }^{2}$ of $527 \mathrm{~cm}^{2}$, in relatively poor agreement with the measurements.

TABLE XV

Parameters Used in Obtaining $\left(\mathrm{L}_{z}{ }^{2}+\tau_{z}\right)$ from Kinetics Experiments

$\begin{array}{lcc} & \begin{array}{c}\text { Loading } \\ \text { No. } 6\end{array} & \begin{array}{c}\text { Loading } \\ \text { No. } 7\end{array} \\ \mathrm{~B}_{\mathrm{r}}{ }^{2}, \mu \mathrm{B} & 203.9 & 173.7 \\ \mathrm{~B}_{\mathrm{z}}{ }^{2}, \mu \mathrm{B} & 135.3 & 164.6 \\ \mathrm{M}_{\mathrm{z}}{ }^{2} / \mathrm{M}_{\mathrm{r}}{ }^{2} & 1.16 & 1.16 \\ \mathrm{I}_{\mathrm{z}}{ }^{2}, \mathrm{~cm}^{2} & 286.4 & 286.4 \\ \tau_{\mathrm{z}}, \mathrm{cm}^{2} & 240.7 & 240.7\end{array}$


Migration Area by Period Reactivity Measurements

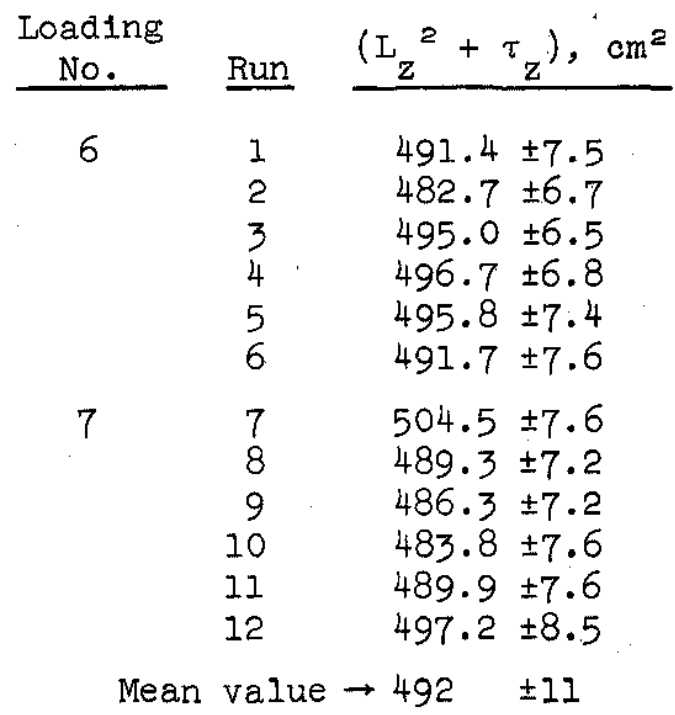

\section{DIFFUSION COEFFICIENT MEASUREMENTS}

\section{Palmedo-Benoist Method}

In the development of a general expression for the space dependent flux in a heterogeneous reactor, Palmedo and Benoist investigated the possiblilty of applying their results to the experimental determination of the radial diffusion coefficient(14). Because their experimental results were quite encouraging, some similar measurements were performed in the EL-4 mockup.

The theory and development of the working expressions of the Palmedo-Benoist method are given in reference 14 and w1ll not be described in detall here. In general, these authors show that the space dependent flux $\Phi(\vec{r})$ in a heterogeneous reactor can be represented by an expression that includes a macroscopic function $\Psi(\vec{r})$, a microscopic function $\phi(\vec{r})$, and an interaction term $\vec{\phi}_{1}(\vec{r})$. This relation $1 \mathrm{~s}$ written

$$
\Phi(\vec{r})=\Psi(\vec{r}) \Phi(\vec{r})-\nabla \Psi(\vec{r}) \cdot \vec{\Phi}_{1}(\vec{r})
$$

Further, an expression for $\vec{\Phi}_{1}(\vec{r})$ is developed which is shown to depend upon the radial diffusion coefficlent. 
To apply the theory to experiment, several expressions are developed that relate to (a) the measurement of the macroscopic flux distributions at different positions in a lattice cell, eg, to flux detector activations at the surface of the cladding of several fuel assemblies both towards and away from the center of the lattlce, and (b) the measurement of the fine structure in one or more cells, eg, to foll act1vations at several angular positions around a fuel assembly.

For (a) above it is shown that for a one region cylindrical reactor

$$
\Phi(\vec{r})=\frac{\Phi_{C}}{\Phi_{t}} J_{\circ}\left(B_{r} r+\epsilon\right)
$$

where

$$
\epsilon \frac{\phi_{c}}{\Phi_{t}}=B_{r} C_{0}\left(\frac{I}{c}-\frac{c}{b^{2}}\right)
$$

$$
\begin{aligned}
& c= \text { distance from center of cell to the point of } \\
& \text { measurement, usualiy the edge of a rod or } \\
& \text { channel. } \\
& b= \text { cylindricized radius of cell } \\
& \Phi_{c}= \text { flux at radius } c \\
& \Phi_{t}= \text { average flux in cell } \\
& B_{r}^{2}=\text { the radial buckling. } \\
& \text { The term } C_{0} \text { is related to the radial diffusion coef- }
\end{aligned}
$$
ficient $D_{r}$ by

$$
\frac{D_{r}}{D_{m}}=\frac{\Phi_{m}}{\Phi_{t}}+\frac{2 \pi}{V_{t}} C_{0}
$$

where

$$
\begin{aligned}
& \mathrm{D}_{\mathrm{m}}=\text { moderator diffusion coefficient } \\
& \phi_{m}=\text { average flux in the moderator } \\
& \mathrm{V}_{t}=\text { volume of the cell. }
\end{aligned}
$$

In equation (24), $\epsilon$ is positive or negative depending on whether the flux is measured on the side of the fuel assembly away from or toward the center of the lattice.

The development also shows that

$$
\Phi_{1}(\vec{r})=C_{0}\left(\frac{1}{c}-\frac{c}{b^{2}}\right) \cos \alpha_{0}
$$


where $\alpha_{0}$ is the angle made by a ine drawn from the point of measurement to the cell center with a line drawn from the pile center to the cell center, 1e, $\alpha_{0}=180^{\circ}$ when the point of measurement is on the side of the assembly directed toward the center of the pile, and $0^{\circ}$ on the opposite side.

Two types of experlments using these developments were performed in the $\mathrm{SE}$. Figures $\mathrm{I2A}$ and $\mathrm{I} 2 \mathrm{~B}$ show the experimental arrangement with gold pins placed at $45^{\circ}$ intervals on the outer surfaces of the fuel housing tubes. Data for the first type of experiment consisted of the (corrected) activations for the gold pins located directly toward and away from the center of the lattice. These data were fitted to equation (24) to determine both $B_{r}$ and $\epsilon$, which were substituted into equation (25) to determine $C_{0}$. Application of equation (26) then give experimental values of $D_{r} / D_{m}$.

The second type of experiment provided a more detailed test of the theory by comparing experimental values of $\phi_{1}$ with those predicted by equation (27). To obtain the exper1mental values, equation (23) was solved for $\Phi_{1}(\vec{r})$ setting $\Psi(\vec{r})=J_{0}\left(B_{r} r\right)$

$$
\Phi_{1}(\vec{r})=\frac{\Phi(\vec{r}) / J_{0}\left(B_{r} r\right)-\Phi(\vec{r})}{\left(B_{r}\right) J_{1}\left(B_{r} r\right) / J_{0}\left(B_{r} r\right)}
$$

The pin activations around the fuel housings gave the values of $\Phi(\vec{r})$ at different radil $r$ and angles $\alpha_{0}$, while the activations of the pins on fuel assemblies at or near the pile center gave $\phi(\vec{r})$. Figures 19 and 20 show the resulting values of $\Phi_{1}$ plotted against $\alpha_{0}$ for typlcal fuel assemblies. Comparison with the theoretical curves obtained from equation (27), also shown in Flgures 19 and 20, shows that the experimental points have the approximate distribution required by the theory but fall below the theory in absolute magnitude. The two theoretical curves given in each figure represent the allowable spread in $\mathrm{C}_{0}$ determined from equation (25). The difference between the theory and the experiment is possibly due to the breakdown of the diffusion theory approximation of the interface between the vold and moderator.

Experiments of the first type above were also performed In the PDP. Gold pins at $\alpha_{0}=0^{\circ}$ and $180^{\circ}$ were placed on the housing tubes of selected fuel assemblies of the 156assembly p1le, as shown in Flgure 21. Four such radial "traverses" were made at right angles to each other. The data were fitted to equation (24), where both $B_{r}$ and $\epsilon$ were determined and then used to obtain $C_{0}$ and $D_{r} / D_{m}$, as in the $\mathrm{SE}$ experiments. 
The values of $D_{r} / D_{m}$ obtained from the SE and PDP measurements are compared in Table XVII.

\section{TABLE XVII}

Summary of Palmedo-Beno1st (14) $D_{r} / D_{m}$ Measurements

\begin{tabular}{|c|c|c|}
\hline & $\mathrm{B}_{\mathrm{r}}{ }^{2}, \mathrm{~m}^{-2}$ & $D_{r} / D_{m}$ \\
\hline $\begin{array}{l}\text { SE, Moderator-centered } \\
\text { SE, Fuel-centered } \\
\text { PDP, Quadrant of pile }\end{array}$ & $\begin{array}{l}9.23 \pm 0.31 \\
8.87 \pm 0.12\end{array}$ & $\begin{array}{l}1.28 \pm 0.03 \\
1.29 \pm 0.02\end{array}$ \\
\hline $\begin{array}{l}1 \\
2 \\
3 \\
4\end{array}$ & $\begin{array}{l}1.81 \pm 0.02 \\
1.79 \pm 0.01 \\
1.80 \pm 0.01 \\
1.81 \pm 0.01\end{array}$ & $\begin{array}{l}1.38 \pm 0.05 \\
1.25 \pm 0.01 \\
1.27 \pm 0.03 \\
1.27 \pm 0.01\end{array}$ \\
\hline
\end{tabular}

The good agreement between the two facllities adds to the confidence in the method because the $B_{r}{ }^{2}$ values are a factor of 5 apart. The calculated value of $D_{r} / D_{m}$ using the Beno1st method is 1.30 .

The experimental method is straightforward and does not require the lattice to be perturbed other than by the placement of the flux detectors in the lattice. The values of $\mathrm{Br}_{\mathrm{r}}{ }^{2}$ obtained in fitting the gold pin activities to equation (24) are somewhat higher than those obtained from the interstitial traverses and the accuracy of the fit is somewhat poorer. The reason for this discrepancy is not clear.

\section{Persson Substitution Method}

A method of obtaining lattice bucklings by substitution techniques using a one group perturbation theory analysis was developed by Persson. (15) In this measurement it is necessary to obtain values of $\Delta D_{z} / D$ and $\Delta D_{r} / D$ resulting from the volding of coolant channels in fuel assemblies. Methods glven by Persson for measuring these parameters were used in this experiment in an attempt to obtain an independent veriflcation of the effects of neutron streaming in the EL-4 mockup fuel assemblies.

The measurements were performed in the PDP in loading No. 7. A diagram of the lattice showing the locations of the test fuel assemblies is given in Figure 22. In the $\Delta D_{z} / D_{z}$ measurement, a single test fuel assembly was placed at the center of the lattice. Th1s assembly was 1dent1cal w1th the other fuel assemblies in the lattice, except that the bottom plug was removed from the housing tube to allow 
$\mathrm{D}_{2} \mathrm{O}$ to rise into the coolant channels. All other fuel assemblies and steel pipe assemblies in the lattice were air filled. The reactor was brought to critical, and the moderator helght was measured. Hellum pressure was then applied to the top of the test fuel assembly to partially expel the $\mathrm{D}_{2} \mathrm{O}$ while the moderator height in the plie was adjusted to maintain criticality. The new critical moderator helght and the hellum pressure were then measured. The expulsion was performed in several steps, and the critical moderator helght and helium pressure were measured at each step unt1l the $D_{2} O$ in the test fuel assembly was completely expelled. Finally, the pressure was reduced to zero, allowing the test fuel assembly to ref1ll with $\mathrm{D}_{z} \mathrm{O}$. Then the critical moderator helght was measured.

In the $\Delta D_{r} / D_{z}$ measurements, two test fuel assemblies were used at symmetrical positions $180^{\circ}$ apart. Four crit1cal runs were made, each one with the two test assemblies at a different radius. The four radial positions are designated $A, B, C$, and $D$ in Figure 22. In each run the critical moderator helght was measured, first with $D_{2} O$ in the test housings, then with the $\mathrm{D}_{2} \mathrm{O}$ completely expelled from the housings, and finally with the housings full of $D_{2} O$. In each run the three measurements were made by adjusting the moderator helght to maintain criticality. The pile was then shut down, the test assembiles moved to a new radius, and the three measurements repeated.

The measured quantities for the two types of measurements are given in Table XVIII. In the $\Delta D_{z} / D$ measurement, the helium pressure was converted into terms of the fraction of fuel assembly which is gas filled. The change in critical moderator helght, $\Delta \mathrm{H}$, is accurate to $\pm 0.005 \mathrm{~cm}$.

The results of the Persson analysis of the se data are given in Table XIX. To facilitate comparison, the value of

$$
\frac{D_{z}^{a 1 r}-D_{z}^{D_{2} O}}{D_{z}^{a 1 r}}
$$

that results directly from the measurement is also given in terms of

$$
\frac{D_{z}^{a i r}-D_{z}^{D_{2} O}}{D_{z}^{D_{2} O}}
$$


The value 0.512 measured in the present experlments agrees favorably with an earlier value of 0.529 measured (10) for the same fuel assemblies at a slightly different lattice pitch (23.7 cm triangular).

$$
\text { The results of the } \frac{D_{r}^{a 1 r}-D_{r}^{D_{2} O}}{D_{z}^{a 1 r}} \text { measurements are also }
$$

given in Table XIX. This measurement had also been performed previously with this type of fuel assembly, but in a reference lattice of $\mathrm{D}_{2} \mathrm{O}$-filled assemblies; in this experiment the reference lattice was air filled. The results do not agree with the earlier experiments or with calculations. Although the reasons for the discrepancy have not been examined in detail, a systematic error 1nvolving the combination of the large bottom reflector and the volded reference lattice is probably responsible. Because of this anomoly it is impossible to obtain a satisfactory measure of the anisotropy in this lattice from these results.

TABIE XVIII

Measured Data, Persson $\triangle D / D$ Measurements

$\begin{array}{rllll}\Delta \mathrm{D}_{\mathrm{z}} / \mathrm{D}_{\mathrm{Z}} & \begin{array}{c}\text { Step } \\ \text { No. }\end{array} & \begin{array}{c}\Delta \mathrm{H}(\mathrm{a}), \\ \mathrm{cm}\end{array} & \begin{array}{c}-\Delta \mathrm{B}_{\mathrm{Z}}{ }^{2}, \\ \mu \mathrm{B}\end{array} & \begin{array}{c}\text { Fraction of Test } \\ \text { Assemb1y Gas F1lied }\end{array} \\ 1 & 0 & 0 & 0 \\ 2 & 0.368 & 0.463 & 0.324 \\ 3 & 0.373 & 0.472 & 0.415 \\ 4 & 0.373 & 0.473 & 0.450 \\ 5 & 0.368 & 0.466 & 0.499 \\ 6 & 0.371 & 0.472 & 0.544 \\ 7 & 0.371 & 0.473 & 0.566 \\ 8 & 0.371 & 0.474 & 0.603 \\ 9 & 0.378 & 0.483 & 0.675 \\ 10 & 0.409 & 0.521 & 0.741 \\ 11 & 0.612 & 0.779 & 0.934 \\ 12 & 0.356 & 0.459 & 0.571 \\ 13 & 0.358 & 0.462 & 0.434 \\ 14 & 0 & 0 & 0\end{array}$

Change in Critical Conditions Upon Expeling $\mathrm{D}_{2} \mathrm{O}$ from

\begin{tabular}{|c|c|c|c|c|}
\hline \multirow[b]{2}{*}{$\Delta D_{r} / D_{z}$} & \multirow{2}{*}{$\begin{array}{c}\text { Test Assembly (b) } \\
\text { Pos1t1on }\end{array}$} & \multirow{2}{*}{$\begin{array}{c}\text { Radlus } \\
\text { In P1le, } \mathrm{cm}\end{array}$} & \multicolumn{2}{|c|}{ Test Assemblies } \\
\hline & & & $\Delta \mathrm{H}, \mathrm{cm}$ & $-\Delta B_{z}{ }^{2}, \mu B$ \\
\hline & A & 48.95 & 1.36 & -1.477 \\
\hline & B & 87.97 & 0.96 & -1.214 \\
\hline & $\mathrm{C}$ & 114.29 & 0.74 & -0.936 \\
\hline & D & 131.60 & 0.69 & -0.877 \\
\hline
\end{tabular}

(a) Change in critical moderator height from Step No. 1. $\mathrm{D}_{2} \mathrm{O}$ helght increased upon expelling $\mathrm{D}_{2} \mathrm{O}$ from assembly.

(b) See F1gure 22. 
Results of Persson $\triangle D / D$ Measurements in PDP

$$
\begin{aligned}
& \frac{D_{z}^{a 1 r}-D_{z}^{D_{2} O}}{D_{z}^{a 1 r}}=0.339 \\
& \frac{D_{z}^{a 1 r}-D_{z}^{D_{2} O}}{D_{z}^{D_{2} O}}=0.512 \\
& \frac{D_{r}^{a 1 r}-D_{r}^{D_{2} O}}{D_{z}^{a 1 r}}=0.280 \\
& \frac{D_{r}^{\text {a1r }}-D_{r}^{D_{2} O}}{D_{z} D_{2}}=0.423
\end{aligned}
$$

\section{GAP CORRECTION CALCULATION}

The vertical buckling measurements for some of the PDP loadings must be corrected for the buckling change caused by the gap where two fuel sections were jolned. Figure 13 shows the location of the gap in the fuel assembly; Figure 14 shows the water heights for the different lattice loadings in relation to the gap. The gap causes a change in $f$, the thermal utilization; in $L^{2}$, the thermal diffusion area; and in $p$, the resonance escape probability. The flux peaking causing the $f$ and $L^{2}$ changes can be measured by foll activations in the fuel assembly. Resonance escape probab1l1ty changes can be estimated by calculations.

To determine the gap correction, the buckling change was calculated for a section of fuel assembly of arbitrary length (but longer than 3 mean free paths for lattice neutrons) in a flat vertical flux. Then the vertical buckling correction for a lattice containing the gap was determined by fluxsquared weighting of the flat flux $\Delta B_{z}{ }^{2}$ in the measured vertical buckling of the lattice. 
The measurement of the flux peaking at the gap was made by placing copper rolls between fuel pellets of the four different types of rods in a representative assembly. Foil activities were corrected to a flat vertical flux as shown in Figure 23.

Consider an $18 \mathrm{~cm}$ section of fuel assembly that includes the gap. If the gap were not present, $f$ would be that of an infinite lattice. When the gap is present in a flat flux, $f$ changes to $f^{\prime}$.

$$
\begin{aligned}
& \frac{l}{f}=\frac{X_{f}+X_{m}+X_{A I}}{X_{f}} \quad \text { where } X_{1}=\left(\phi \Sigma_{a} V\right)_{1} \\
& \frac{I}{f^{\prime}}=\frac{x_{f}^{\prime}+x_{m}+x_{A I}+X_{A I}^{\prime}}{x_{f}^{\prime}} \\
& \frac{1}{f^{\prime}}=\left(\frac{1}{f}\right) \frac{\phi}{\phi_{a}^{1}}+1-\frac{\phi}{\phi_{a}^{\prime}}+\frac{\phi^{\prime \prime}}{\phi} \cdot \frac{\Sigma_{a}^{\mathrm{A}}}{\Sigma_{a}^{f}} \cdot \frac{1-a}{a}
\end{aligned}
$$

$f($ from calculation $)=0.9449$

$a=$ fraction of fuel section that is fuel $=0.9333$

$\Phi=$ thermal neutron flux in fuel assembly without gap

$\phi^{\prime}=$ thermal neutron flux in fuel assembly with gap

$\phi^{\prime \prime}=$ thermal neutron flux in aluminum connectors between fuel rods

$\frac{\phi}{\phi}=0.9899 ; \frac{\phi^{\prime \prime}}{\phi}=1.137$

$\Sigma_{a}(A I)=0.0123 \mathrm{~cm}^{-1} ; \Sigma_{a}($ fuel $)=0.169 \mathrm{~cm}^{-1}$

$f^{\prime}=0.9362$ (flat flux)

$\frac{\Delta f}{f}=\frac{f-f^{\prime}}{f}=9.2 \times 10^{-3}$.

Two effects are included in $\Delta \mathrm{p} / \mathrm{p}$ in going from a fuel section without a gap to a section with a gap. First, the fuel-to-moderator ratio is reduced because fuel is removed from the section. Second, the resonance integral, RI, changes because of a reduction of the mass of $\mathrm{UO}_{2}$ and an increase in the effective surface. 


$$
\begin{gathered}
1-p=\frac{N_{f}}{\xi \Sigma_{s}} \frac{V_{U}}{V_{m}} R I \\
\frac{\Delta p}{p}=\frac{1-p}{p}\left[\left(\frac{V_{U}}{V_{m}}\right)^{-1} \Delta \frac{V_{U}}{V_{m}}+\frac{\Delta R I}{R I}\right] \\
\left(\frac{V_{U}}{V_{m}}\right)^{-1} \Delta \frac{V_{U}}{V_{m}} \cong(1-a)=0.0667 \\
\frac{\Delta R I}{R I}=\frac{13.3}{R I}\left(\frac{S}{M}\right)^{\frac{1}{2}}\left[\frac{\Delta S}{M}-\frac{S}{M} \frac{\Delta M}{M}\right]=-2.97 \times 10^{-2} \\
\frac{\Delta p}{p}=-3.6 \times 10^{-3} \text { (flat flux). }
\end{gathered}
$$

The correction to be applied to the measured bucklings because of the fuel gap is determined by calculating the difference in buckling between the fuel section with the gap and that of a fuel rod w1th no gap.

Starting from a two group formulation, the buckling difference in the gap is given by

$$
\begin{gathered}
k_{\infty}=\eta \in p f=\left(1+L^{2} B^{2}\right)\left(1+\tau B^{2}\right) \\
\Delta k_{\infty} / k=\frac{\Delta f}{f}+\frac{\Delta p}{p}=\frac{\left(L^{2}+\tau\right) \Delta B^{2}+B^{2} \Delta L^{2}}{\left(1+L^{2} B^{2}\right)\left(I+\tau B^{2}\right)} \\
\Delta B^{2}=\left[\frac{\Delta f}{f}+\frac{\Delta p}{p}\right]\left(1+L^{2} B^{2}\right)\left(1+\tau B^{2}\right)-\frac{\Delta f}{f} L^{2} B^{2}
\end{gathered}
$$

where $\Delta L^{2}=\frac{\Delta f}{f} I^{2}$

$$
\Delta B^{2}=0.11 \mathrm{~m}^{-2} \text { (flat flux). }
$$

Figure 24 shows the net buckling correction as a function of vert1cal buckling. These results were applied wherever necessary. 


\title{
ANCILLARY MEASUREMENTS
}

\author{
Moderator Flux Traverse \\ To determine if the placement of the copper polson \\ tubes at the corners of the lattice cells appreciably sup- \\ pressed the moderator flux, an experimental flux traverse \\ was made, using copper w1re, along the diagonal of a square \\ lattice cell that contained a copper tube and, for reference, \\ a cell that did not have copper. The results of the tra- \\ verses are shown in Figure 25, normalized to THERMOS (11) \\ calculations for the fuel cell and copper tube. The traverse \\ through the copper-contalning cell shows some suppression \\ when compared to the $D_{2} O$ traverse, but for most of the points \\ it is not a signiflcant amount because of overlapping error \\ bars. On the basis of this experiment, the change in the \\ moderator disadvantage factor was considered negligible for \\ the determination of $\left(\tau_{z}{ }^{2}+\tau_{z}\right)$.
}

\section{Reflector Savings}

The critical buckling was determined for four lattice loadings that had $\mathrm{D}_{2} \mathrm{O}$ reflectors. In two of the loadings the 332 and 120 assembly plles - both the vertical and radial buckling components were measured by pin irradiations. For the other two pile sizes, only the vertical buckling was determined by critical water helght means. The radial buckling was then inferred from one of the other plie sizes and the anisotropy in migration area as described previously (see page 15). Reflector saving is defined as the difference between the extrapolated and cylindricized radil of the core. Reflector thickness is defined as the difference between the radius of the reactor tank and the cylindricized radius of the core.

Figure 26 shows reflector savings as a function of reflector thickness for all reflected lattices, including the two points from the SE.

\section{ACKNOWLEDGEMENT}

The authors wish to express their appreciation to P. A. Lourme, Centre D'Études Nucléaires de Saclay, France, for his many helpful suggestions and stimulating technical discussions during his visit to this laboratory in the early phases of this work. 


\section{REFERENCES}

1. Horowitz, J. "Le Projet El 4". Energle Nucléaire 3, No. 6, pp. 369-71 (1961).

2. Ballley Du Bo1s, B. and R. Naudet. "Presentation de I'avant-Projet EL 4". Energle Nuclealre 3, No. 6, pp. $372-89$ (1961).

3. Dunklee, A. E. The Heavy Water System of the Process Development. E. I. du Pont de Nemours \& Co., Savannah River Laboratory, Aiken, S. C. USAEC Report DP-567 (1961).

4. Towler, O. A., Jr. and J. W. Wade. "Exponent1al Measurements in Heavy-Water Systems". Chem. Eng. Progr. Symp. Ser. 52, No. 19, 177-81 (1956).

5. Axtmann, R. C., et al. Initial Operation of the Standard P1le. E. I. du Pont de Nemours \& Co., Savannah R1ver Laboratory, Aiken, S. C. USAEC Report DP-32 (1953).

6. Graves, W. E. R-3/Adam Lattice Buckling Measurements In the Process Development PIle. E. I. du Pont de Nemours \& Co., Savannah River Laboratory, Alken, S. C. USAEC Report DP-598 (1961).

7. Driggers, F. E. "BSQ - An IBM-704 Code to Calculate Heavy Water Lattice Parameters". Panel on Heavy Water Lattices, International Atomic Energy Agency, Vienna, Austria, February 18-22, 1963.

8. Benolst, P. General Formulation of the Diffusion Coefficlent in a Heterogeneous Medium Allowing Cavities. Commissarlat a I'Energle Atomique, Paris, France. Report SPM-522 (1958).

9. Beno1st, P. A Simple New Expression for the Radical Diffusion Coefficient for Fueled Channels. Commissariat a 1'Energle Atomique, Centre d'Etudes Nucléa1res, Saclay, France. Report SPM-710 (1962).

10. Graves, W. E. Analysis of the Substitution Technique for the Determination of $\mathrm{D}_{2} \mathrm{O}$ Lattice Bucklings. E. I. du Pont de Nemours \& Co., Savannah River Laboratory, Alken, S. C. USAEC Report DP-832 (1963). 
11. Honeck, H. C. THERMOS. A Thermalization Transport Theory Code for Reactor Lattice Calculations.

Brookhaven National Laboratory, Upton, N. Y. USAEC Report BNI-5826 (1961).

12. Baumann, N. P. Resonance Integrals and Self-Shielding Factors for Detector Folls. E. I. du Pont de Nemours \& Co., Savannah River Laboratory, Aiken, S. C. USAEC Report DP-817 (1963).

13. Keepin, G. R. "Neutron Data for Reactor Kinetics". Nucleonics 20, No. 8, pp. 150-56 (1962).

14. Palmedo, P. E. and P. Beno1st. "Interaction of Macroscoplc Flux and Fine Structure in Heterogeneous Reactors." IAEA Symposium on Exponential and Critical Experiments, Amsterdam (September 1963).

15. Persson, R. One Group Perturbation Theory Applied to Substitution Measurements w1th Vo1d. RFX-74 (1961). 


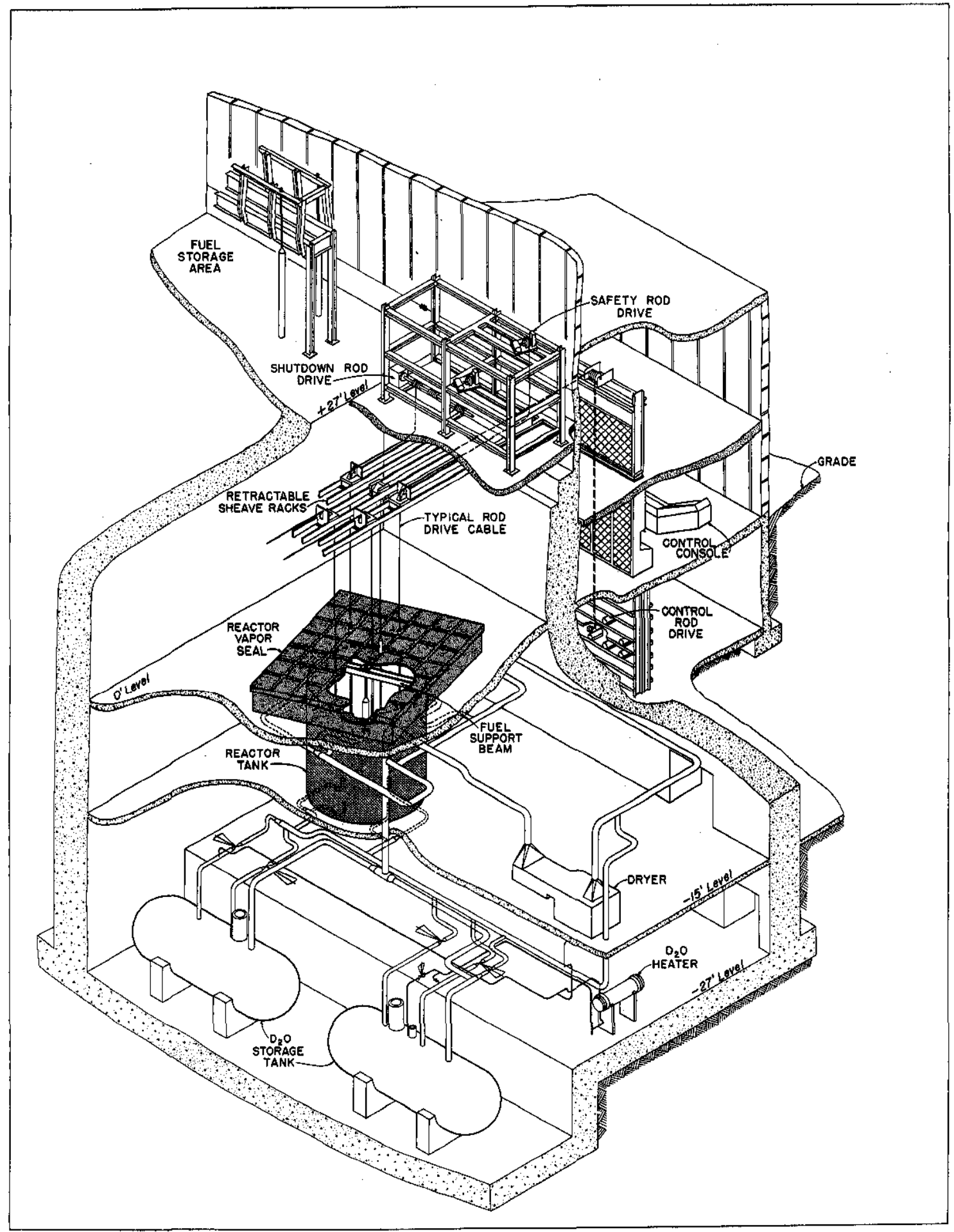

FIG. I ISOMETRIC DRAWING OF PROCESS DEVELOPMENT PILE 


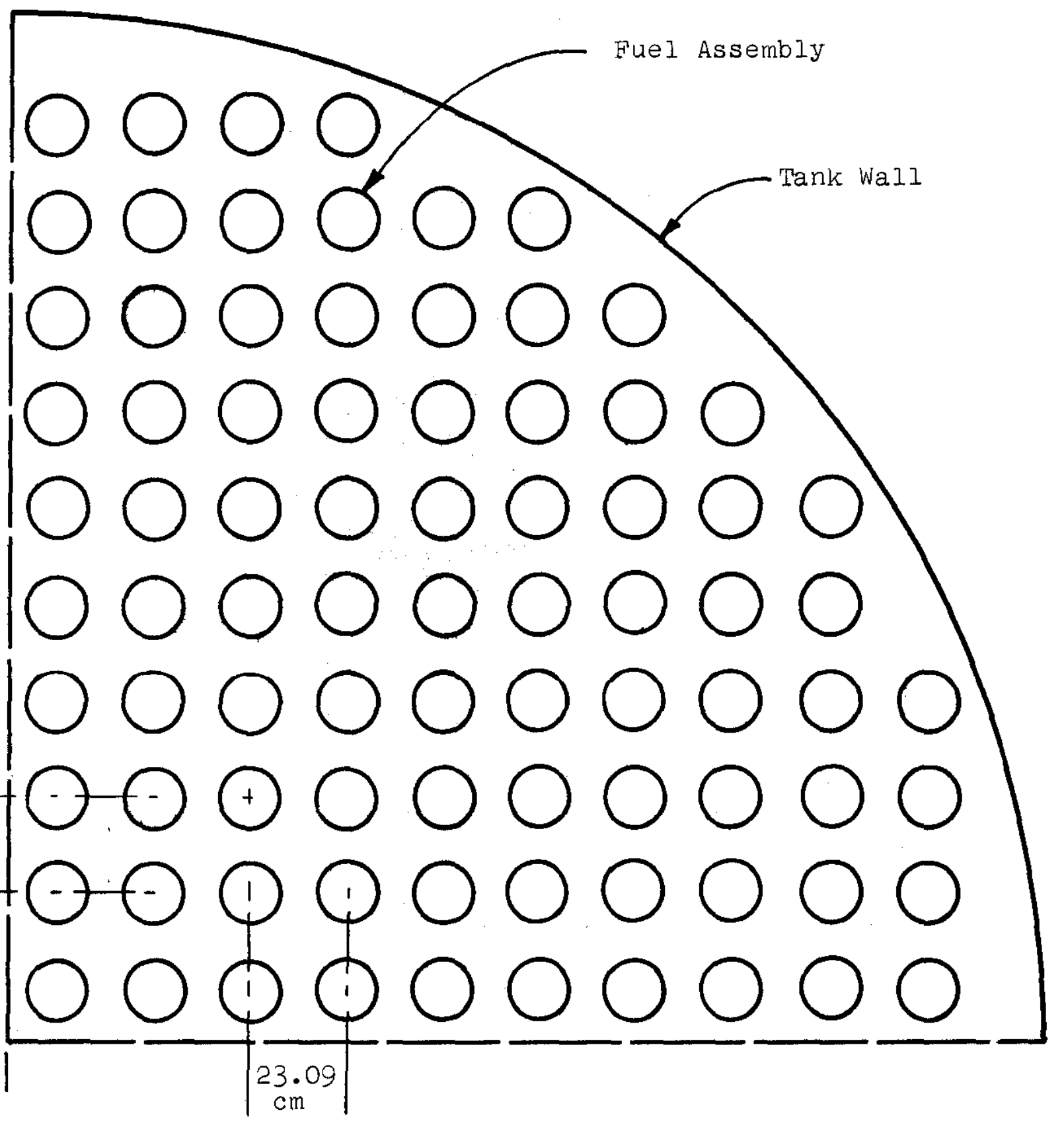

FIG. 2 QUADRANT OF PDP LOADING NO. 1 332 Fuel Assemblies 


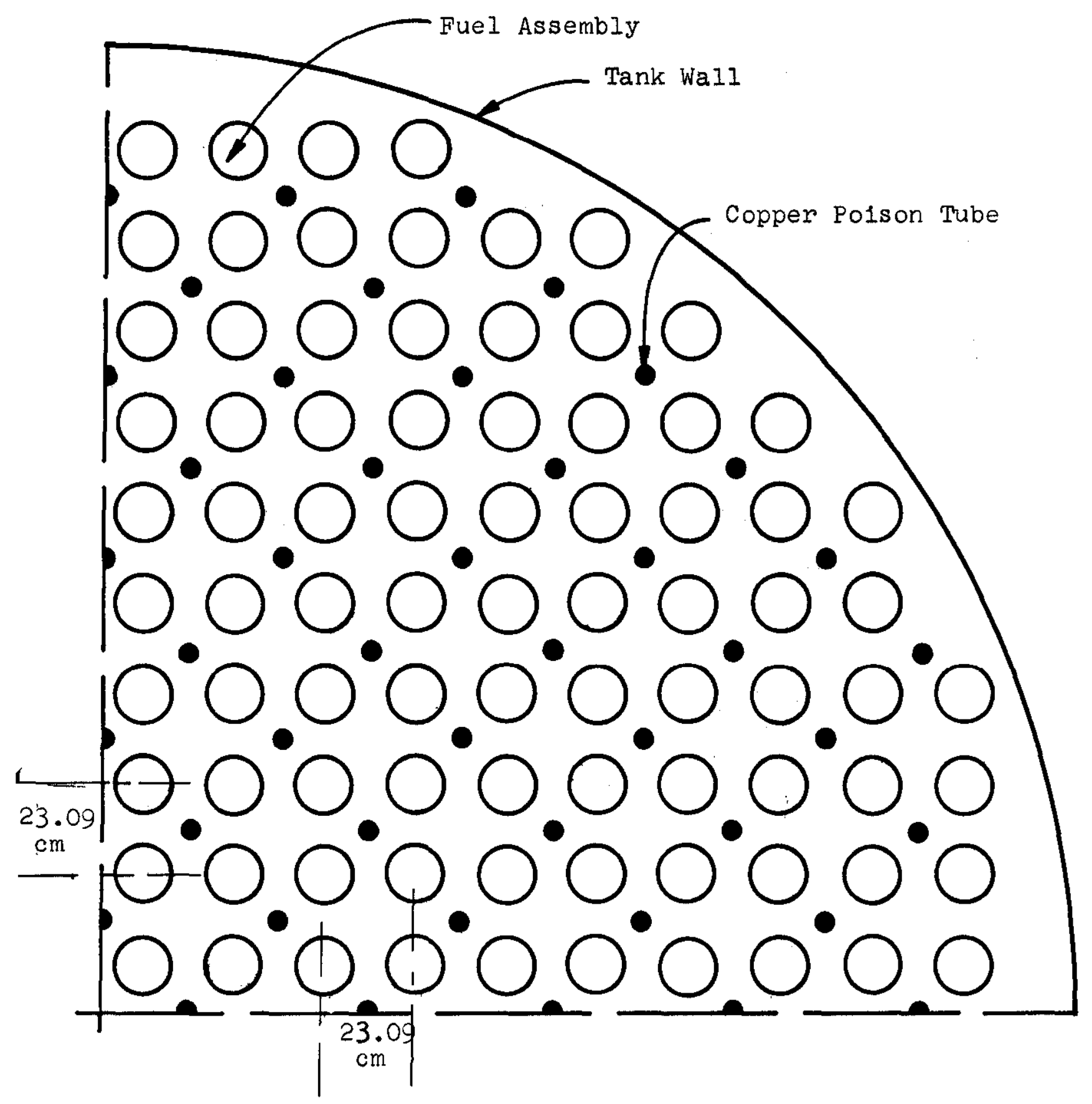

FIG. 3 QUADRANT OF PDP LOADING NO. 2 332 Fuel Assemblies

156 Copper Tubes 


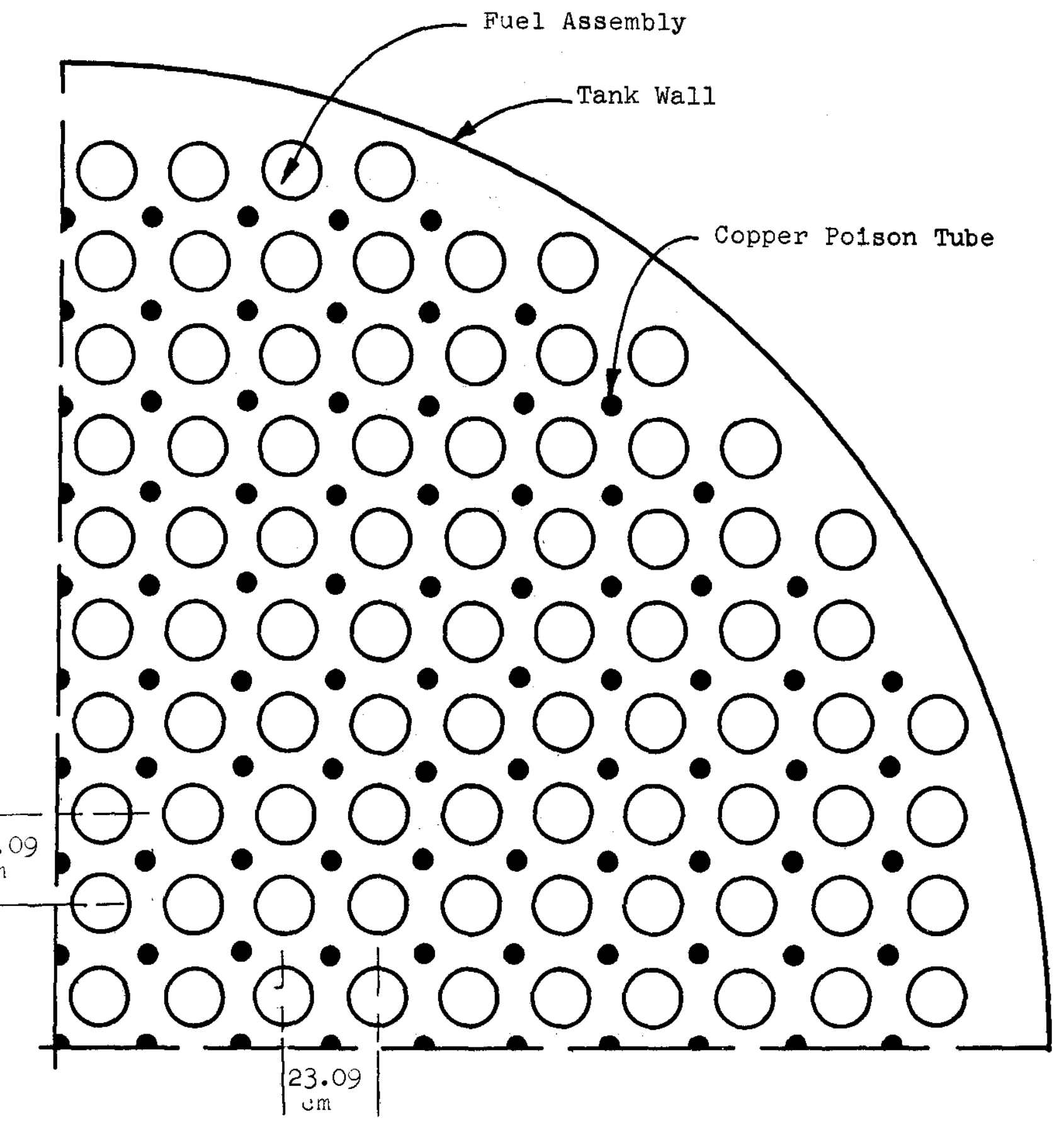

FIG. 4 QUADRANT OF PDP LOADING NO. 3

332 Fuel Assemblies

301 Copper Tubes 


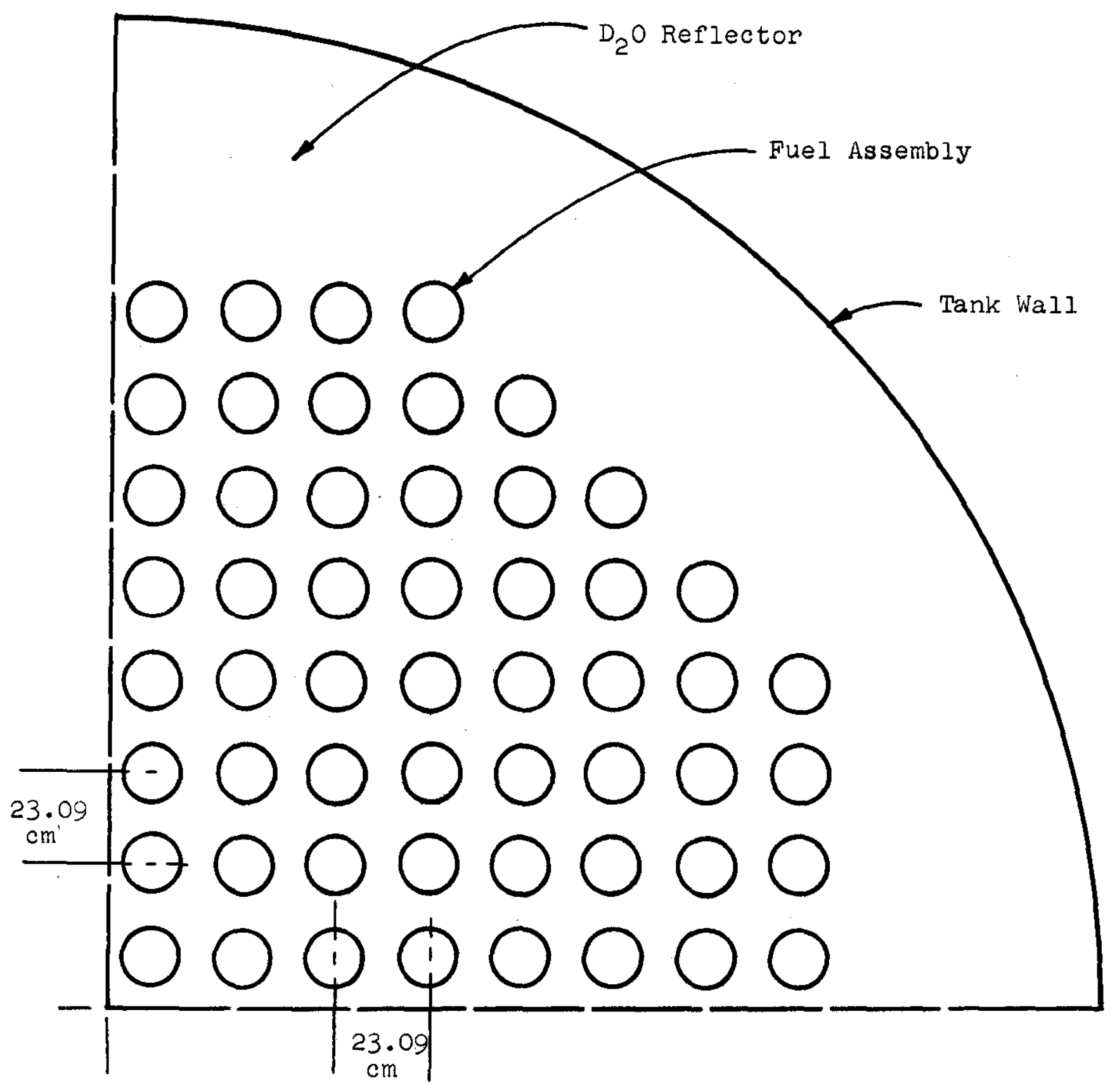

FIG. 5 QUADRANT OF PDP LCADING NO. 4 216 Fuel Assemblies

$\mathrm{D}_{2} \mathrm{O}$ Reflector

$-46-$ 


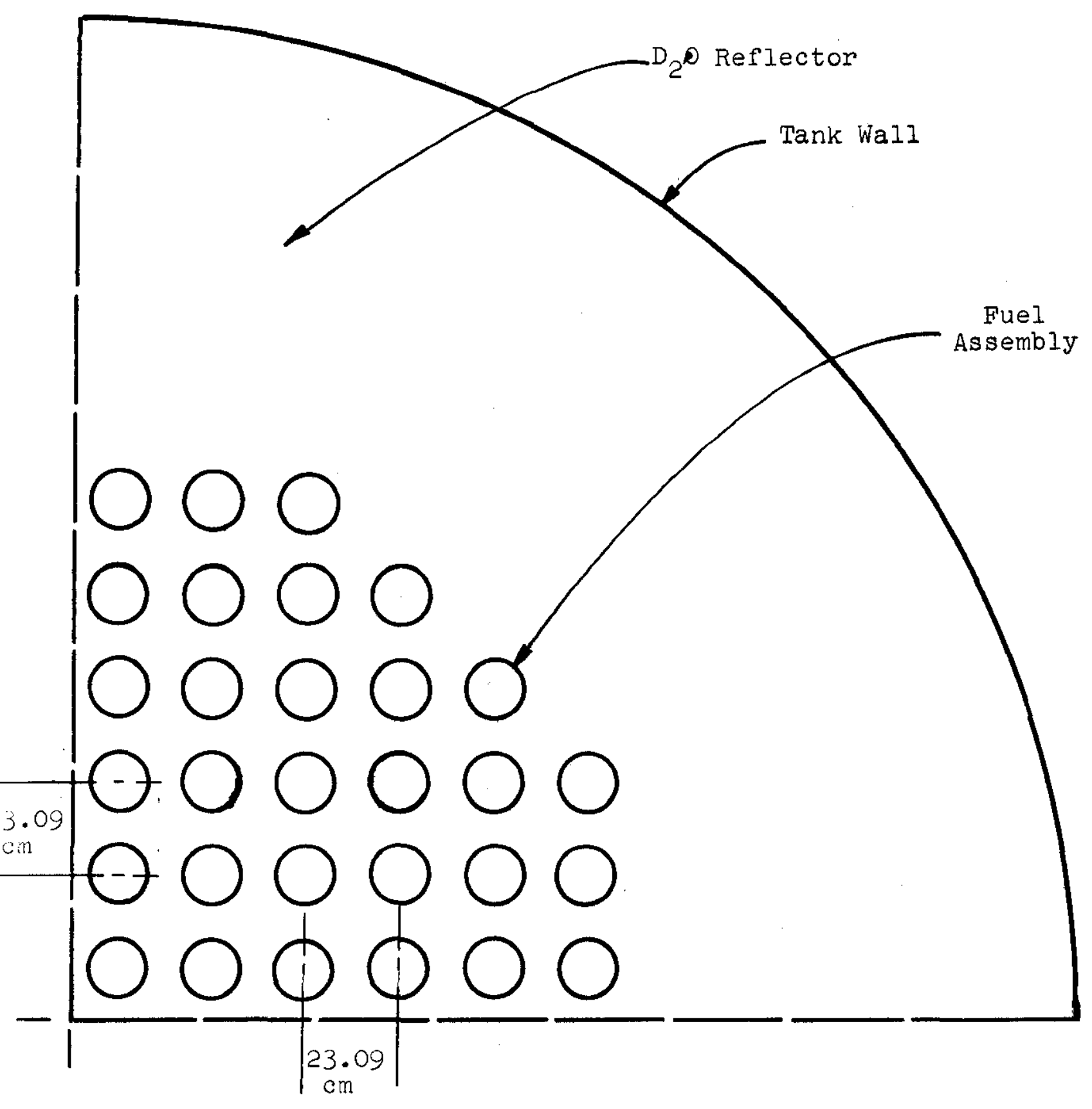

FIG. 6 QUADRANT OF PDP LOADING NO. 5

$$
\begin{gathered}
120 \text { Fuel Assemblies } \\
D_{2} \mathrm{O} \text { Reflector }
\end{gathered}
$$

$$
-47-
$$




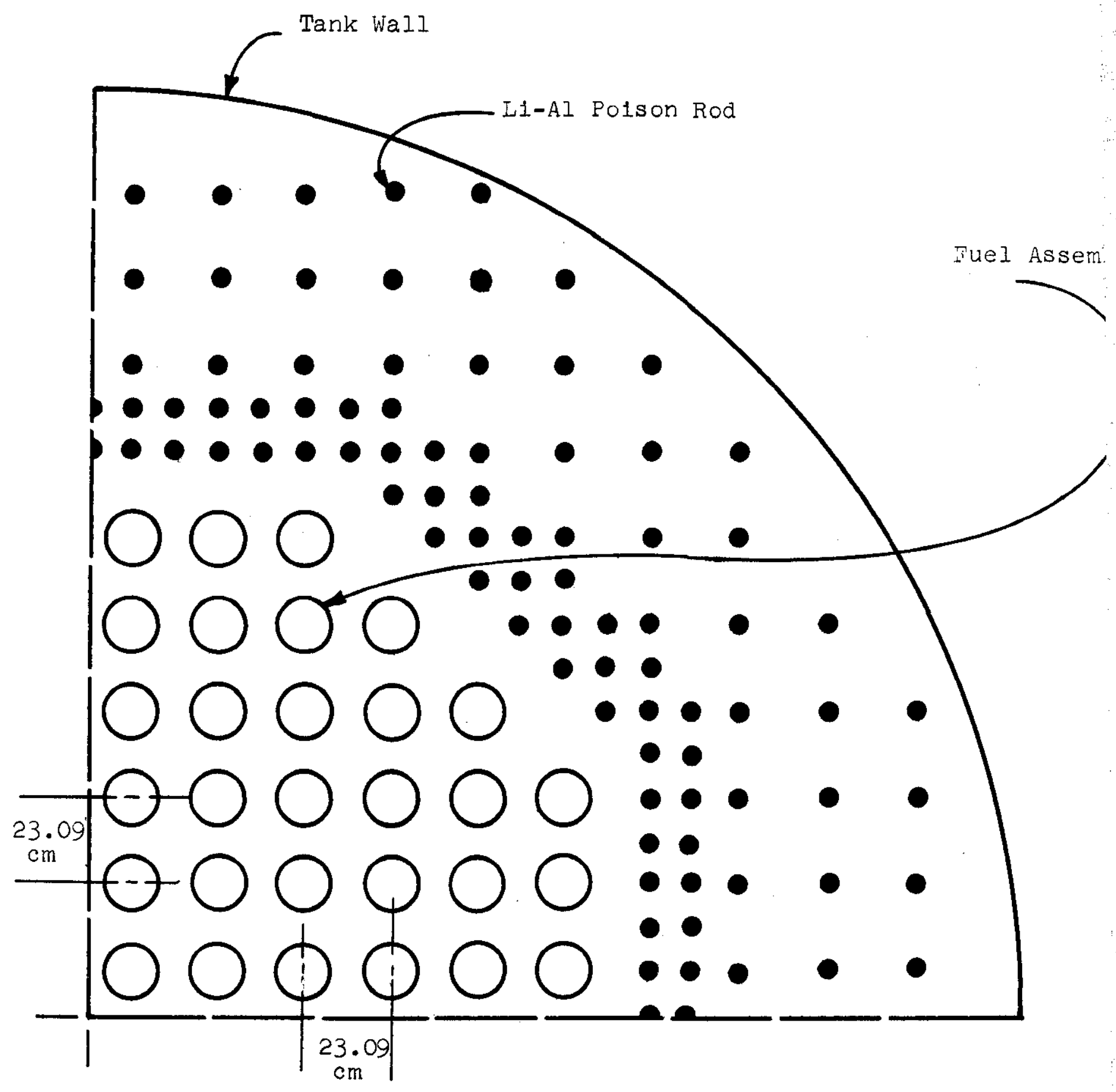

FIG. 7 QUADRANT OF PDP LOADING NO. 6

120 Fuel Assomblies

Li-Al Poisoned Reflector 


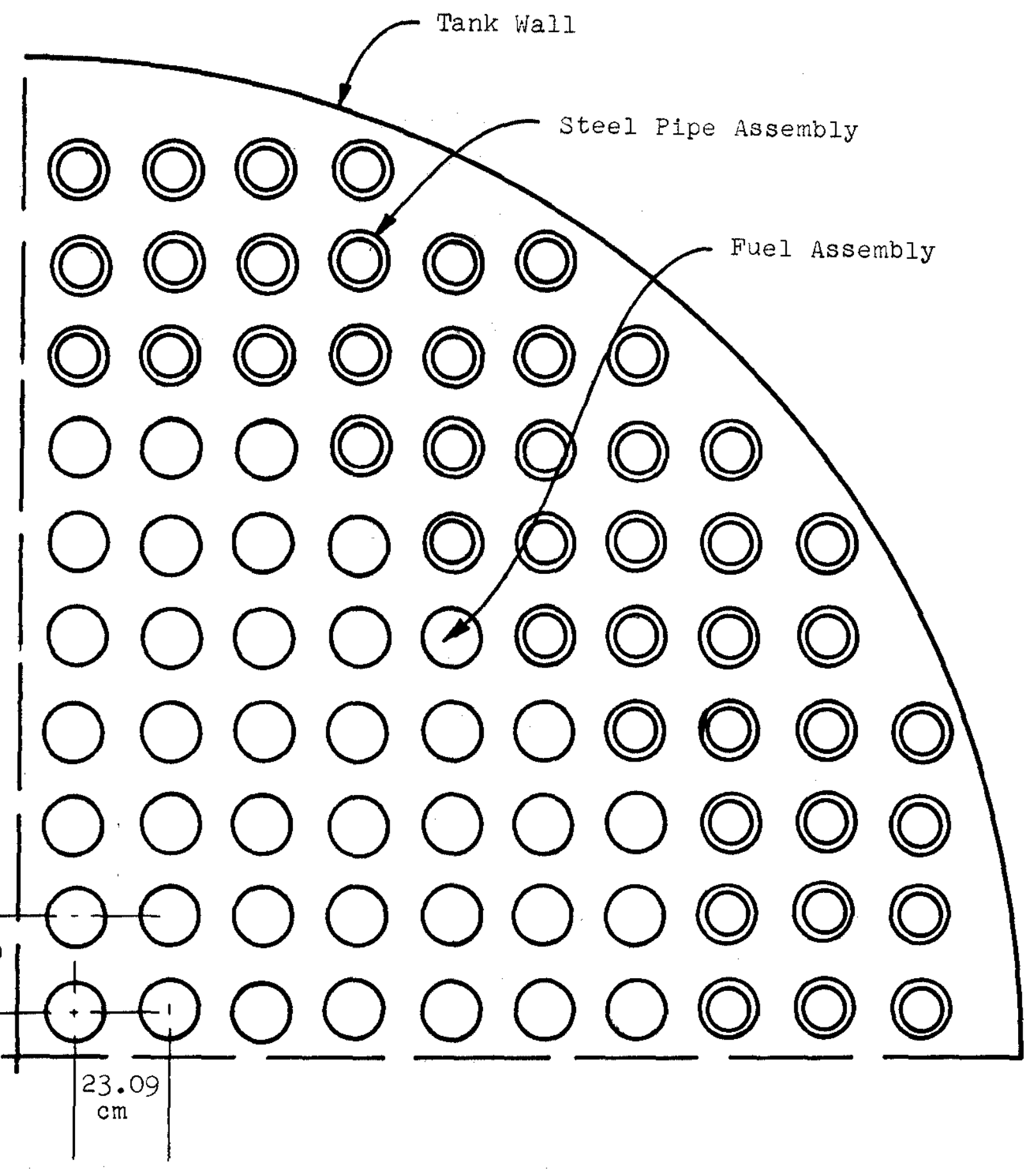

FIG. 8 QUADRANT OF PDP LOADING NO. 7

$$
\begin{aligned}
& 156 \text { Fuel Assemblies } \\
& 160 \text { Steel Pipe Assemblies }
\end{aligned}
$$

$$
-49-
$$




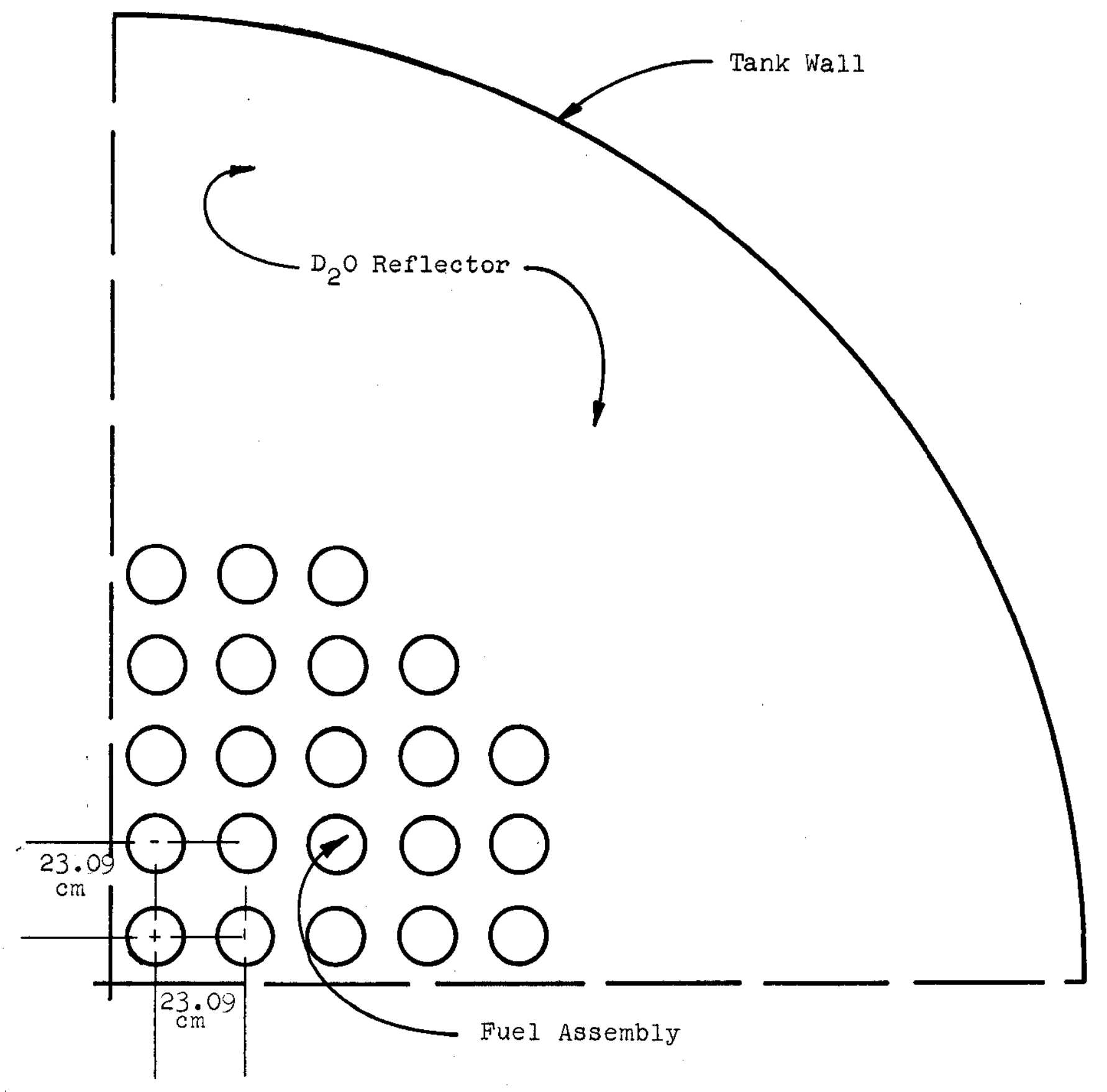

FIG. 9 QUADRANT OF PDP LOADING NO. 8

88 Fuel Assemblies

$\mathrm{D}_{2} \mathrm{O}$ Reflector 


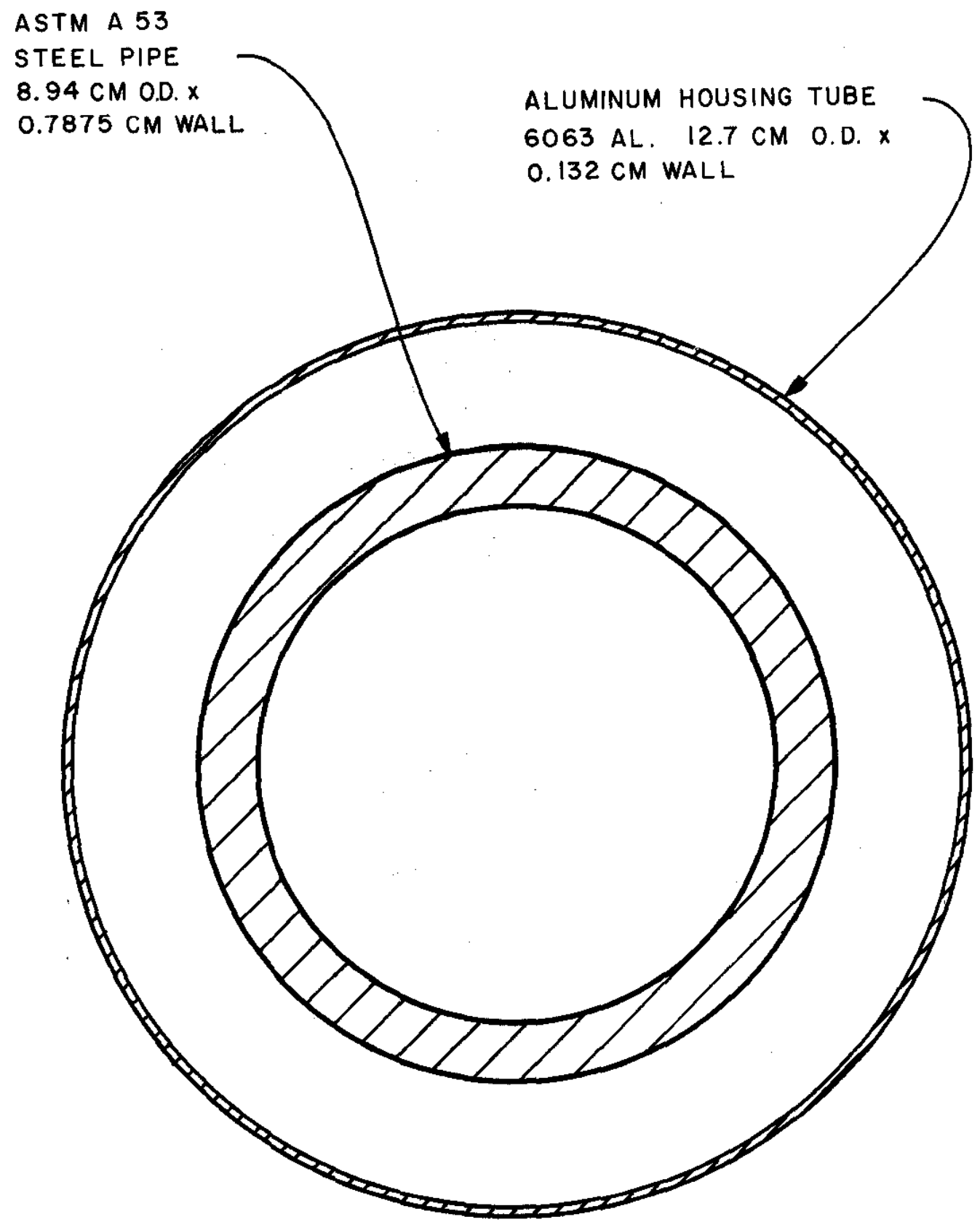

FIG. 10 CROSS SECTION OF STEEL PIPE ABSORBER ASSEMBLY 


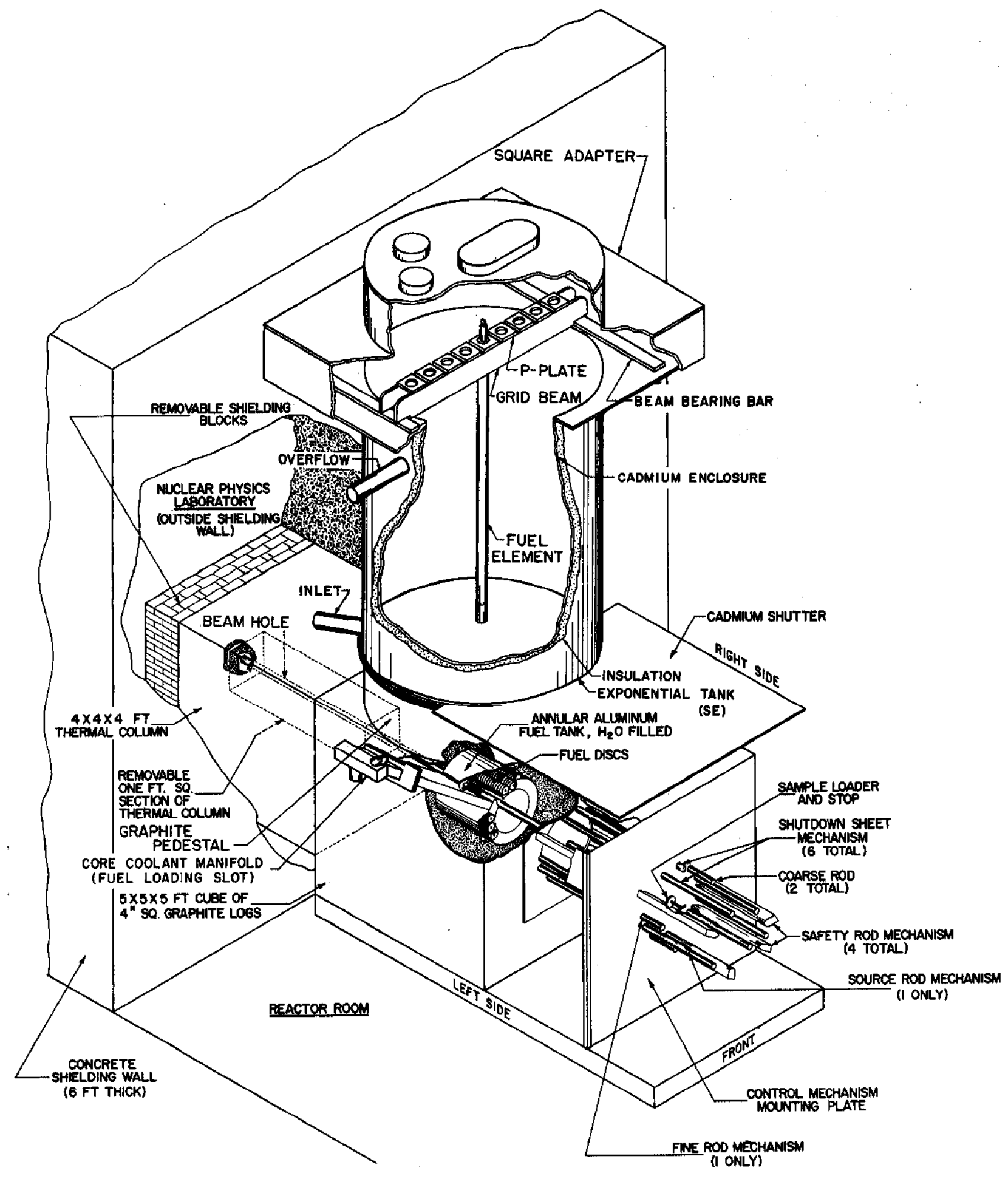

FIG. 11 ISOMETRIC VIEW OF STANDARD PILE AND EXPONENTIAL TANK 


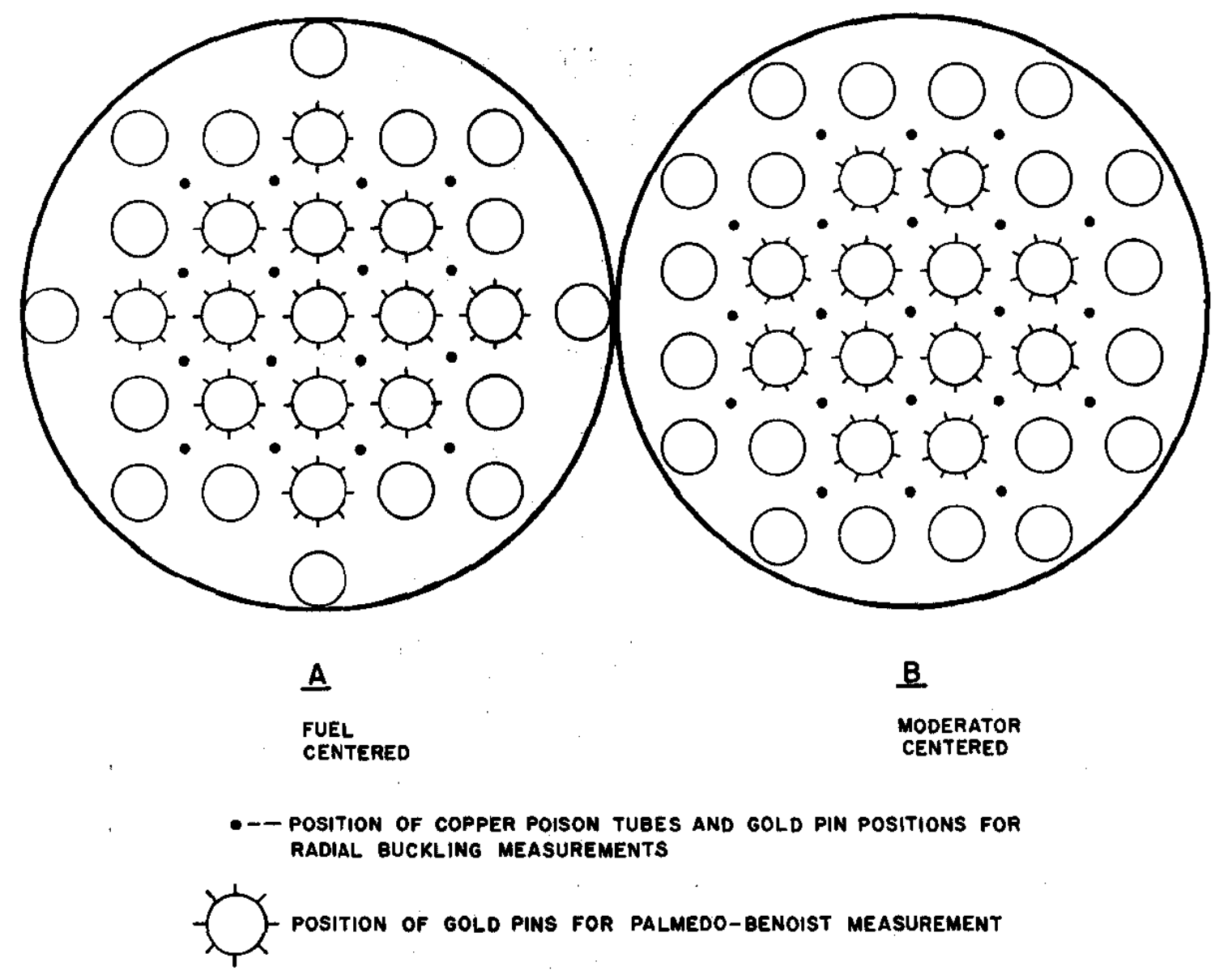

FIG. 12 SE LOADINGS 


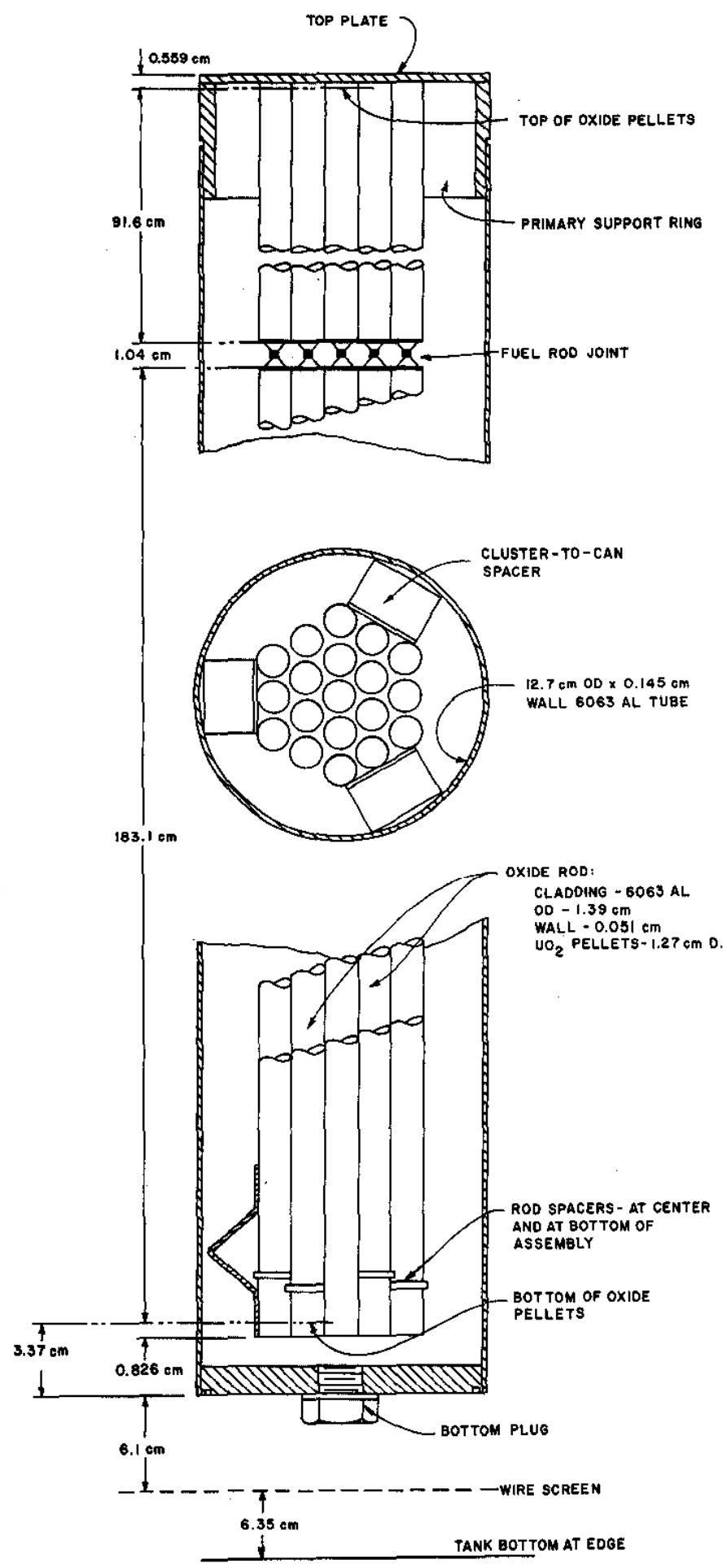

FIG. 13 NINETEEN-ROD $U_{2}$ FUEL ASSEMBLY 


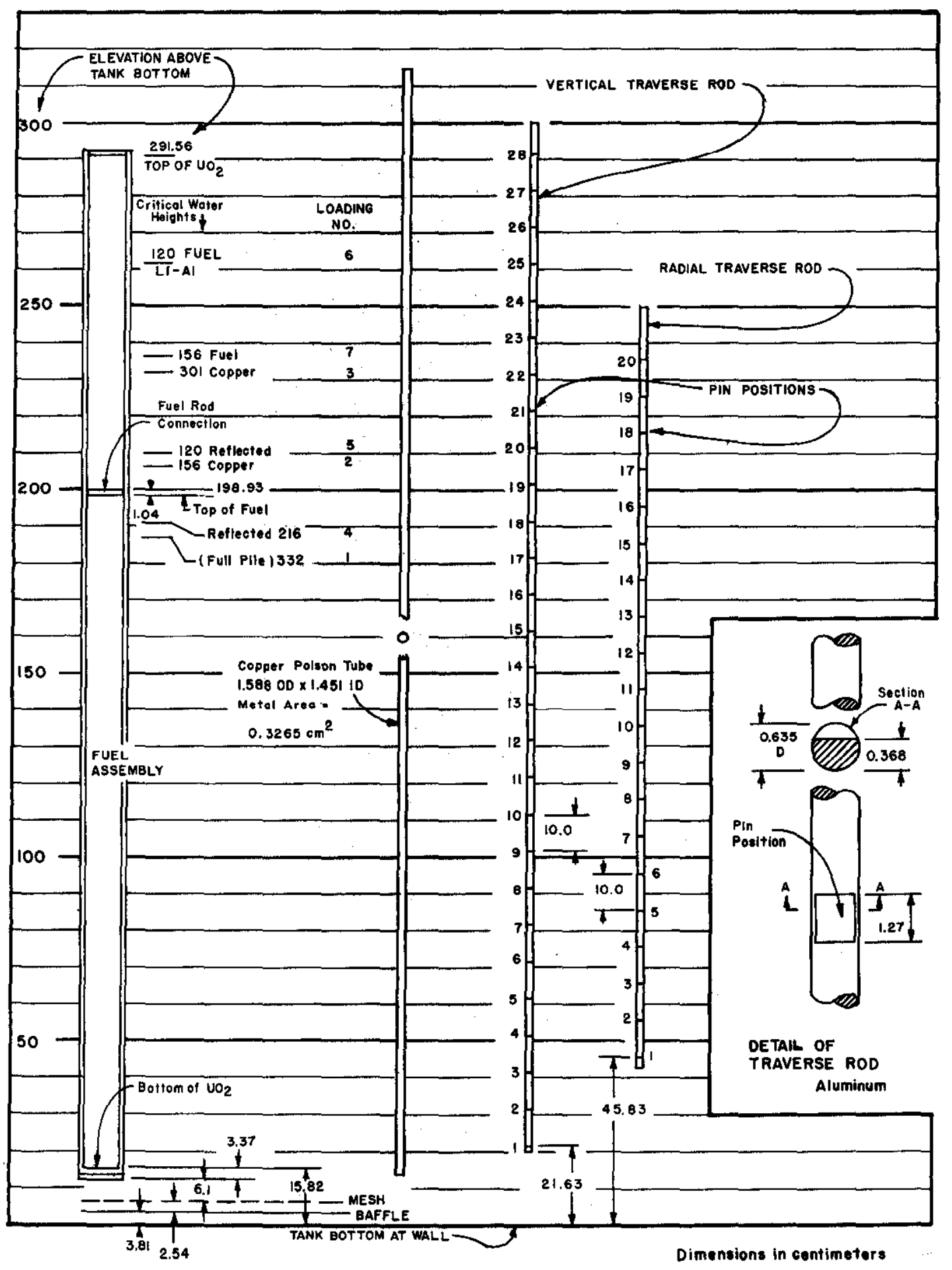

FIG. 14 VERTICAL SECTION OF LATTICE COMPONENTS IN EL - 4 EXPERIMENTS 


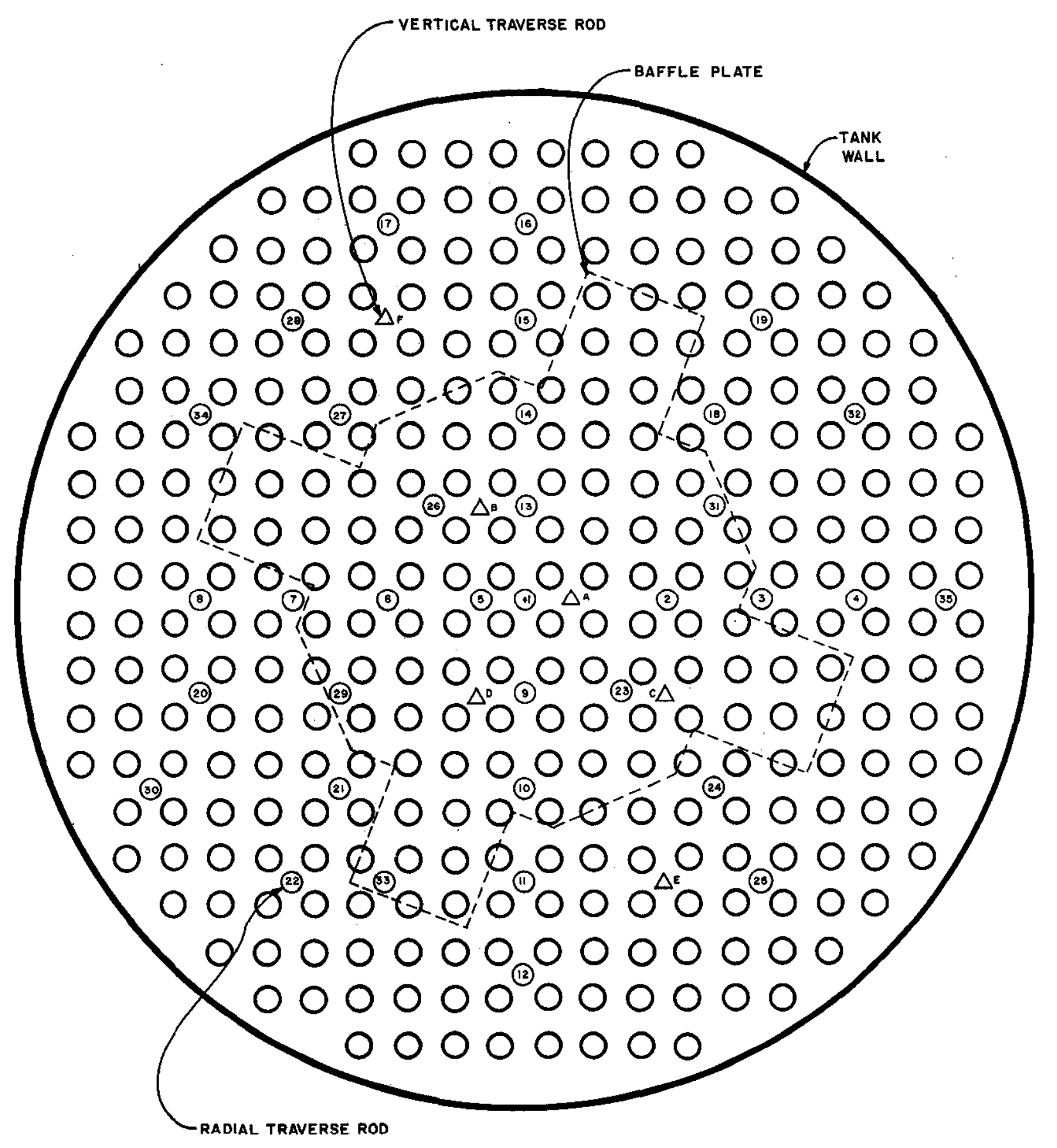

FIG. 15 GOLD PIN LAYOUT LOADING NO. 1 


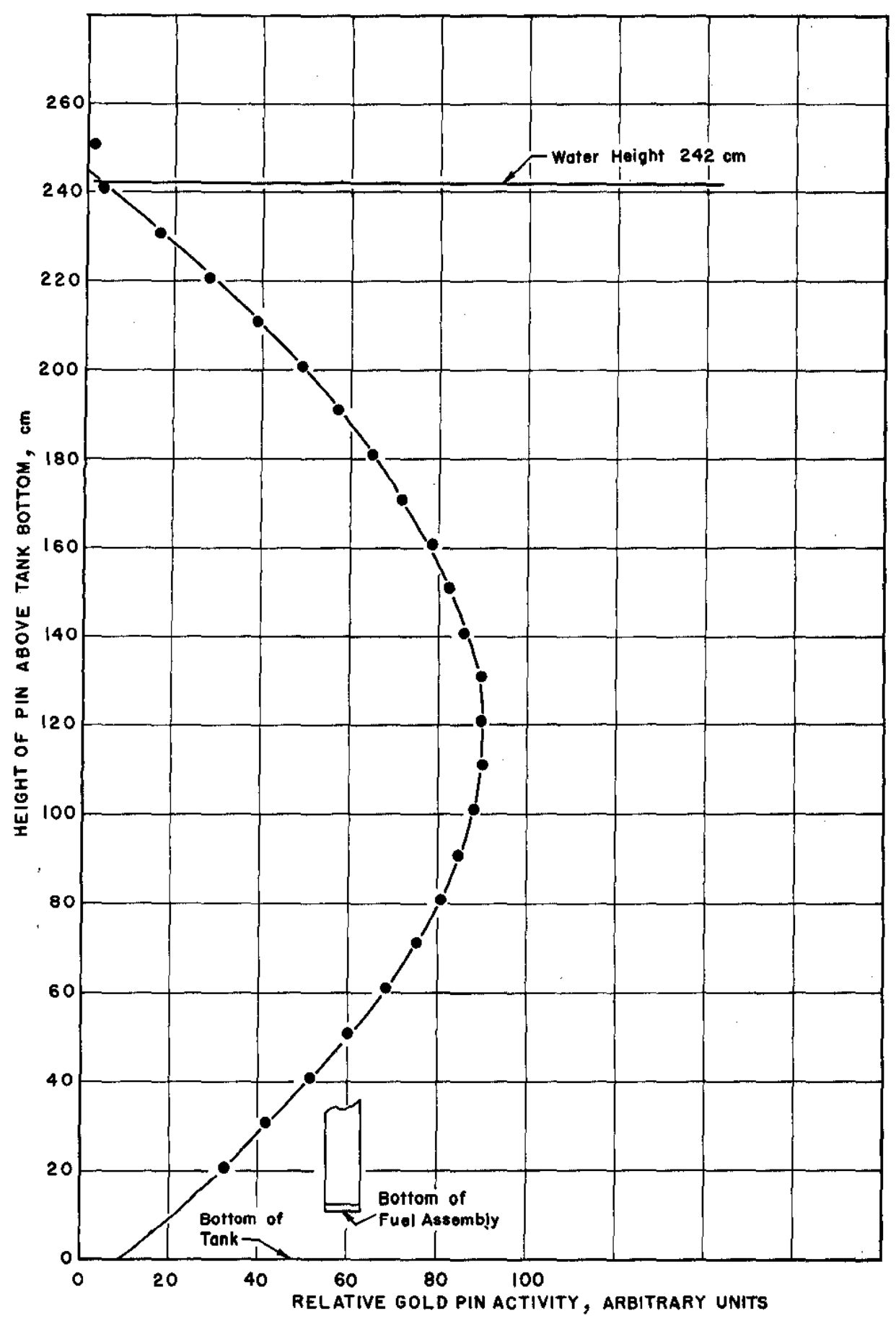

FIG. 16 VERTICAL GOLD PIN TRAVERSE LOADING NO. 7 


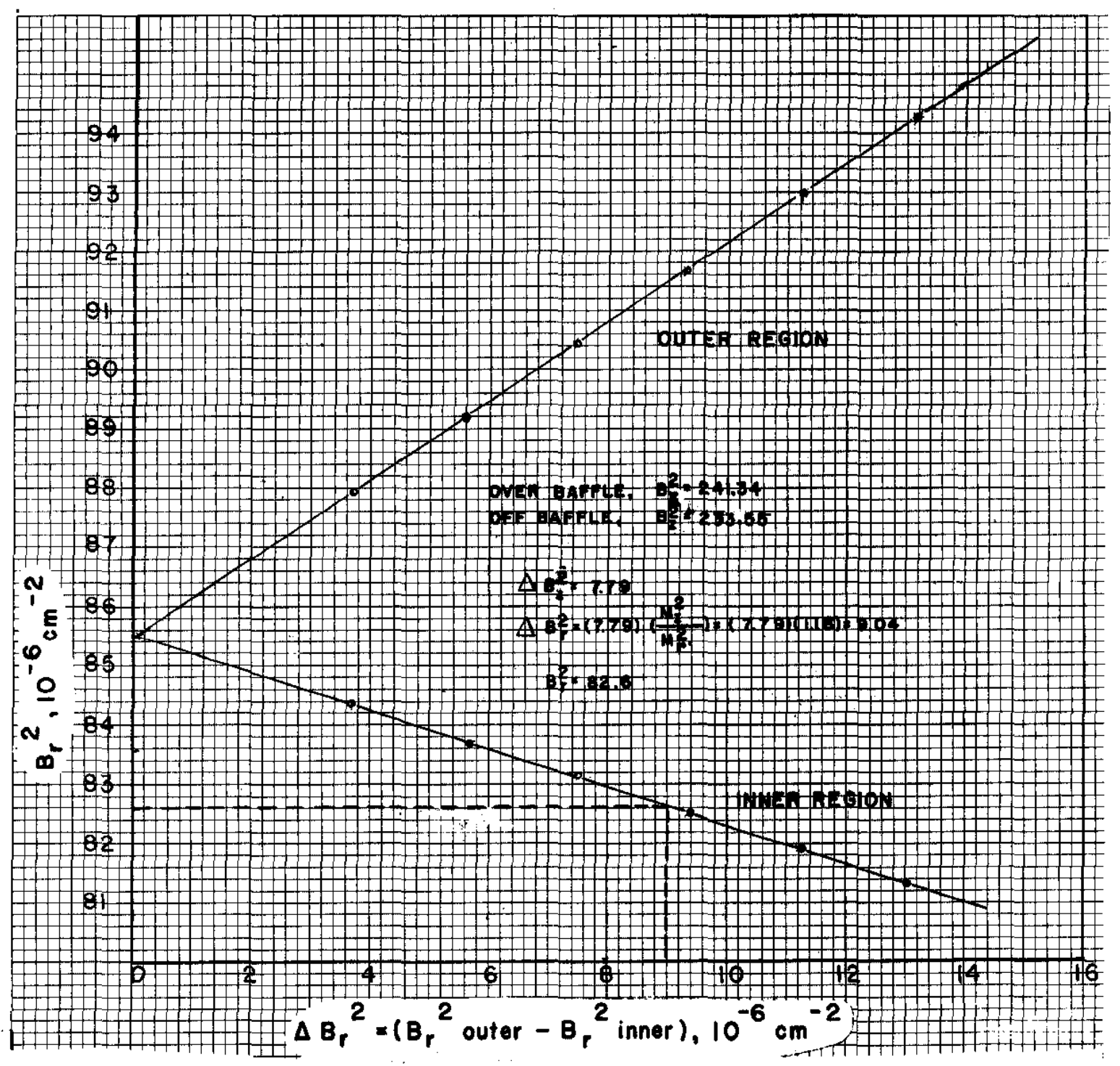

FIG. 17 TWO REGION CODE RESULTS 


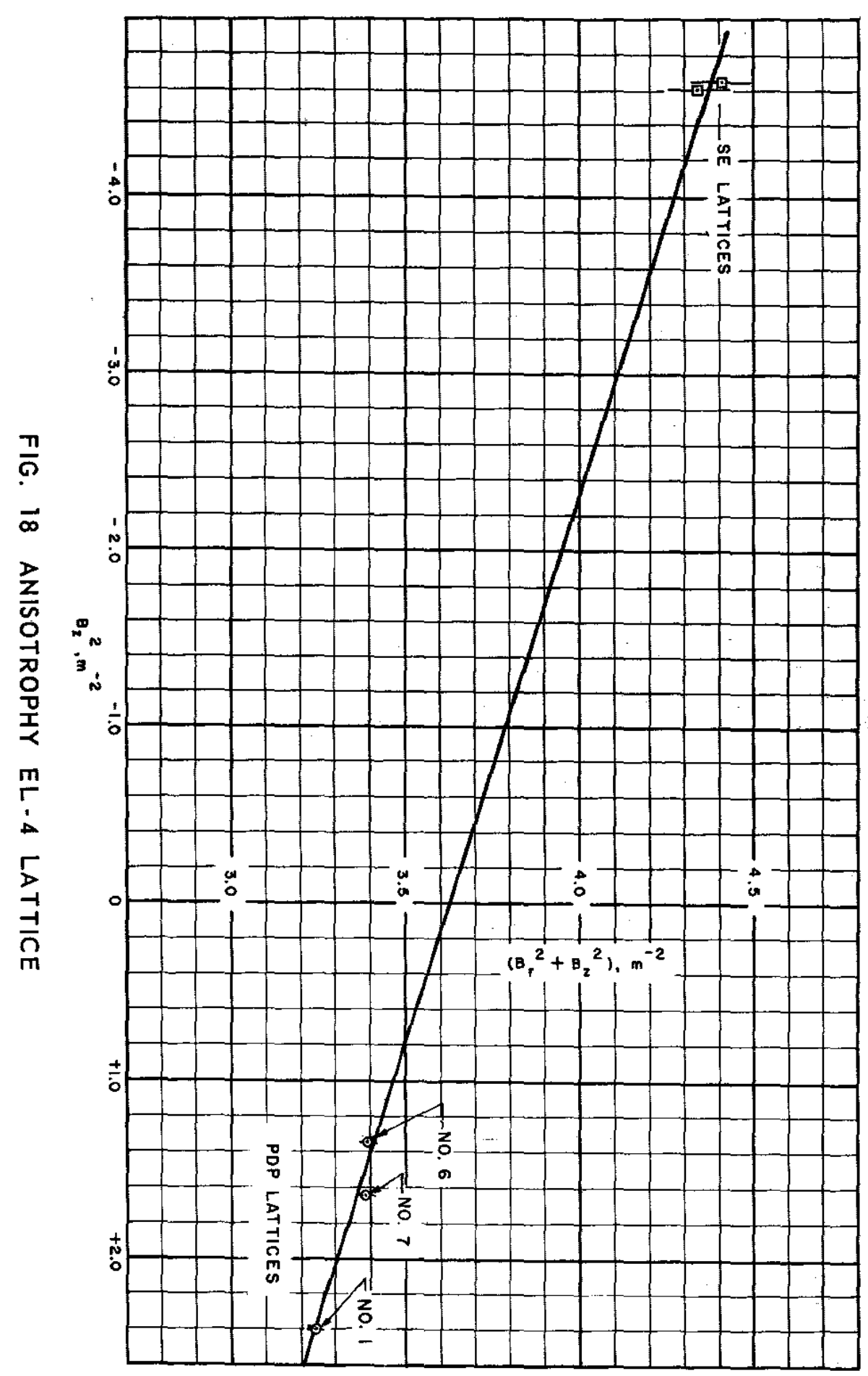




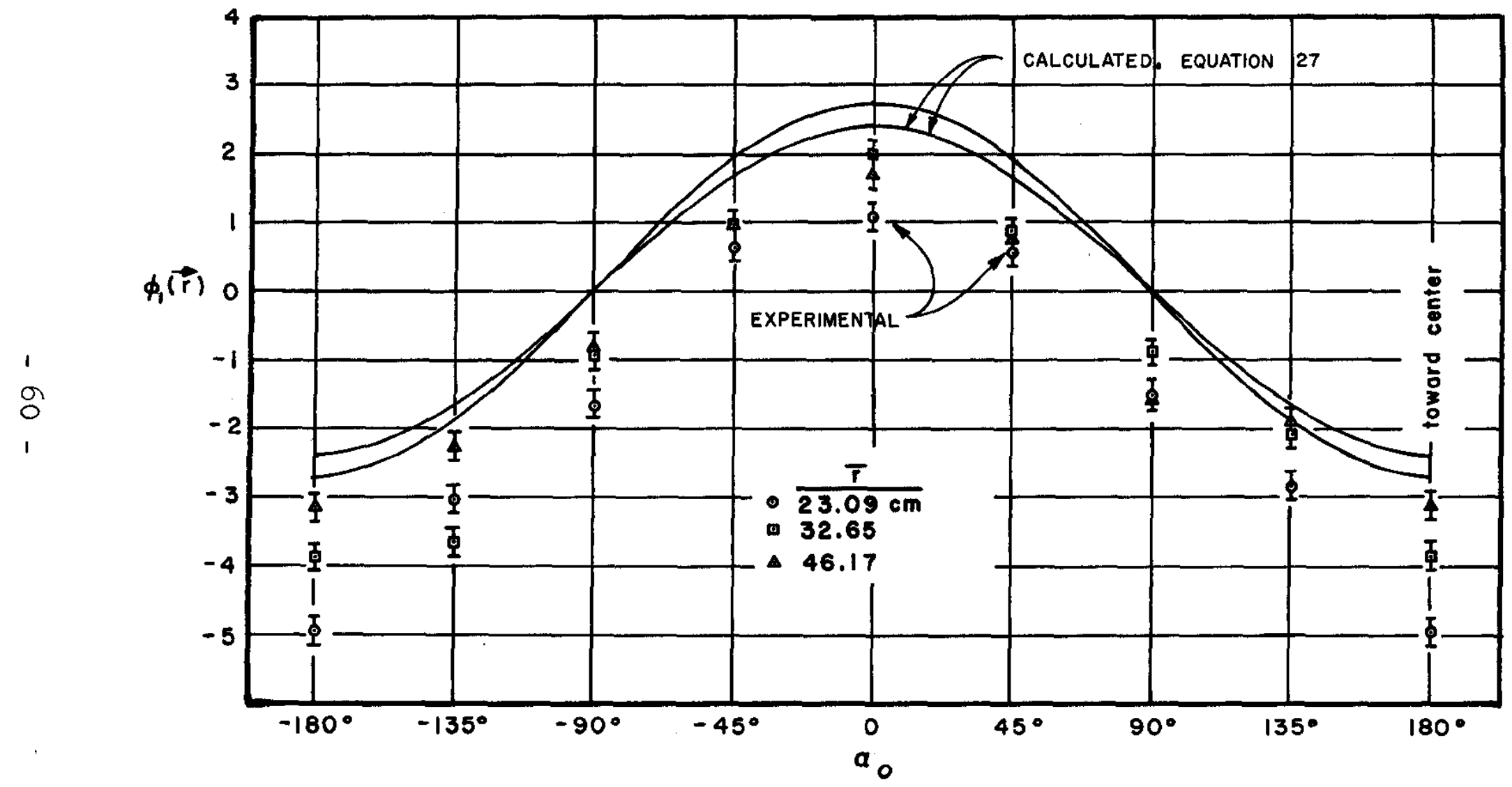

FIG. 19 FUEL CENTERED LATTICE, PALMEDO. BenOIST METHOD FOR $\mathrm{D}_{\mathrm{r}} / \mathrm{D}_{\mathrm{m}}$ 


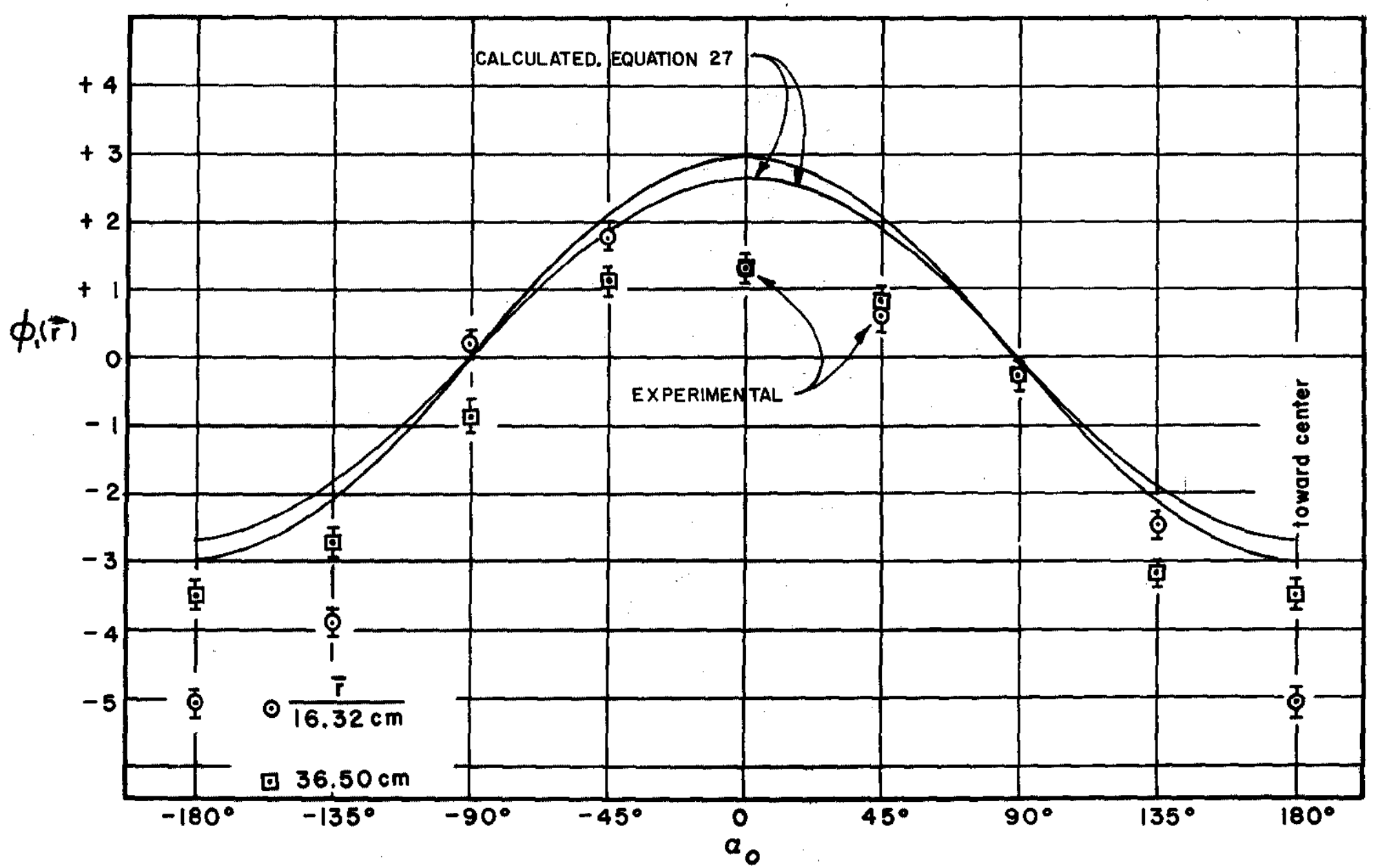

FIG. 20 MODERATOR CENTERED LATTICE, PALMEDO-BENOIST METHOD FOR $D_{\mathrm{r}} / \mathrm{D}_{\mathrm{m}}$ 


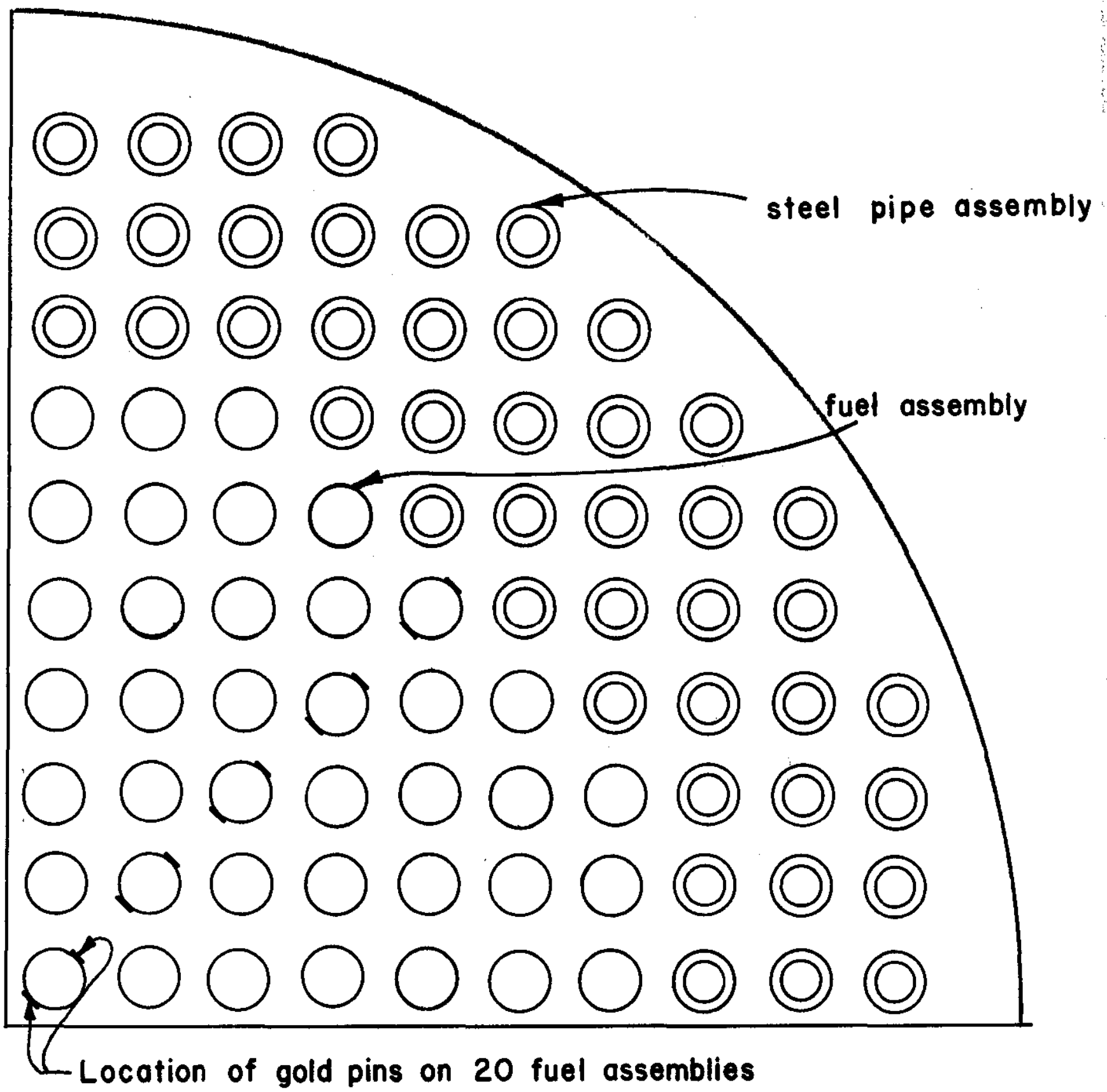

FIG. 21 PALMEDO-BENOIST MEASUREMENT OF $D_{r} / D_{m}$ IN PDP 


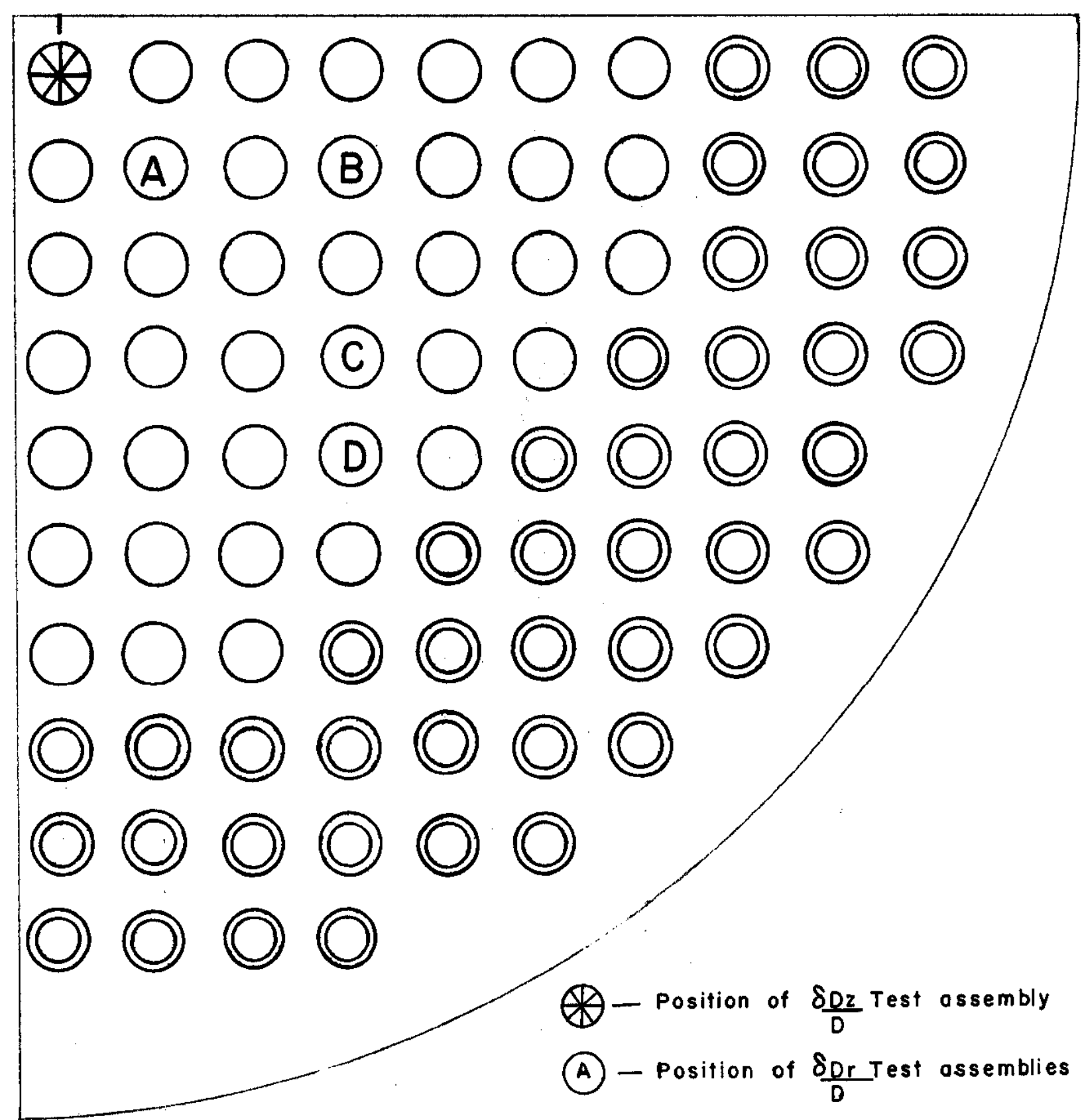

FIG. 22 TEST FUEL POSITIONS $\delta$ D/D MEASUREMENTS IN PDP 


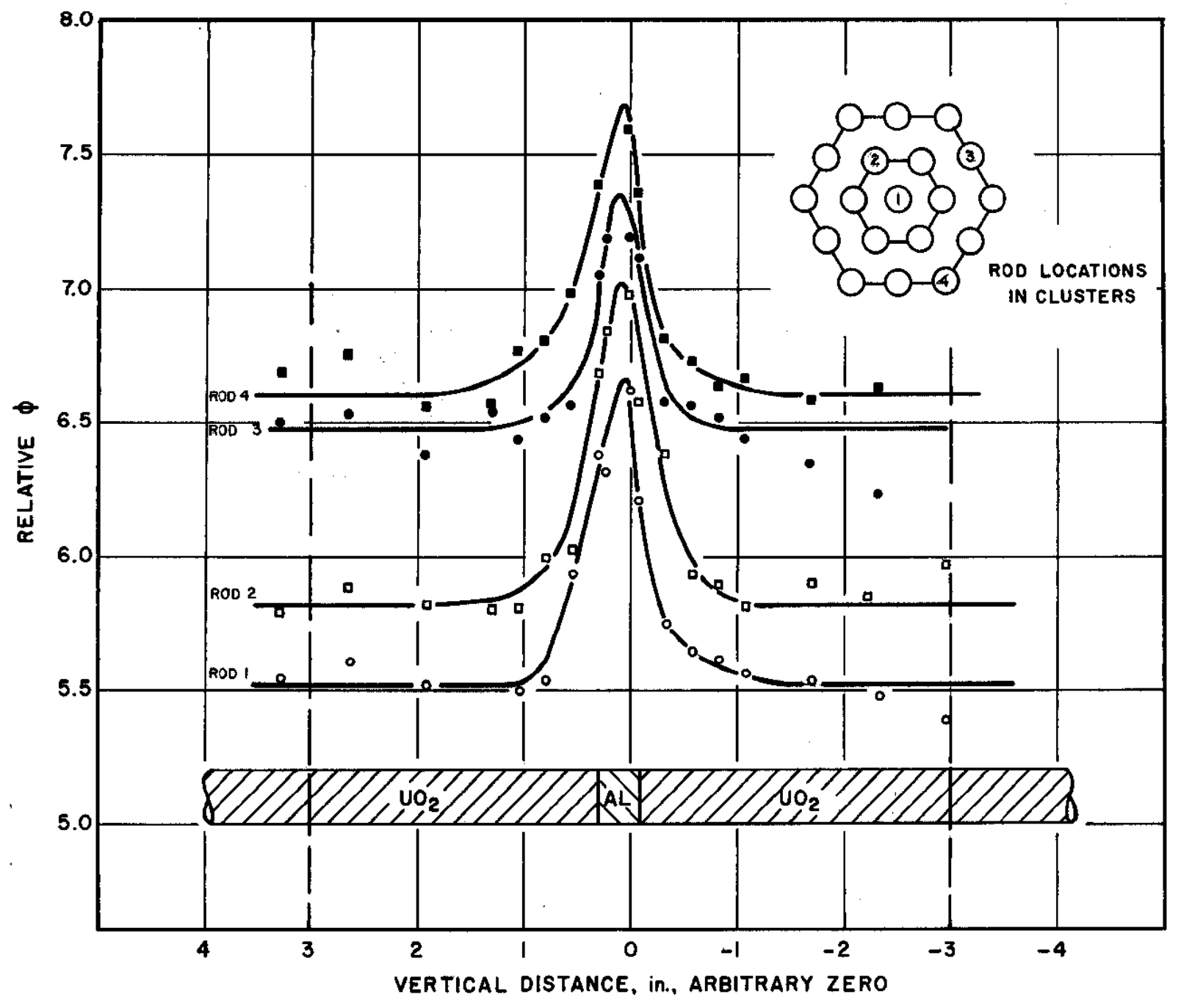

FIG. 23 CORRECTED FOIL ACTIVATIONS ACROSS FUEL GAP 


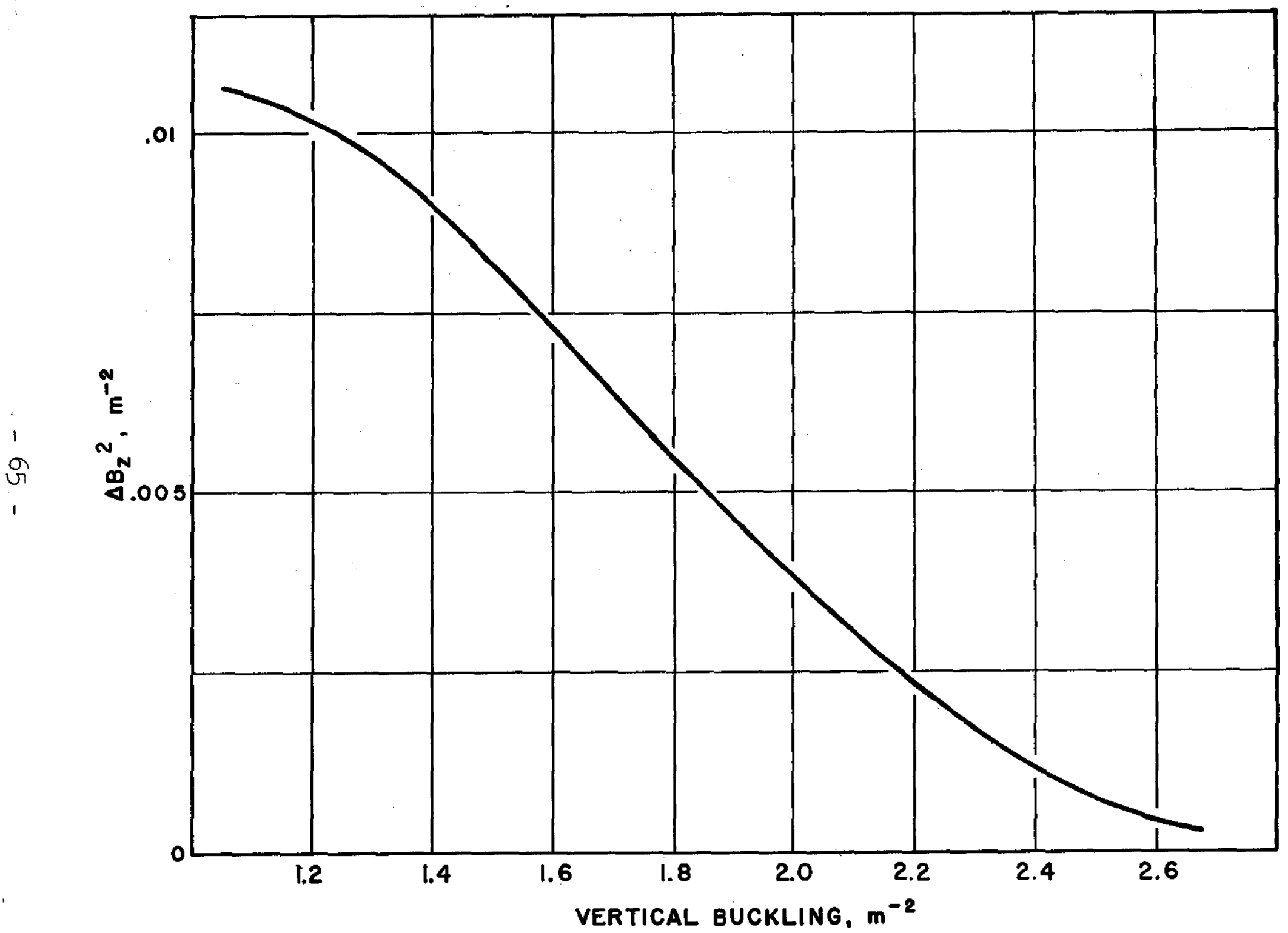

FIG. $24 \Delta B_{Z}{ }^{2}$ DUE TO FUEL GAP VS VERTICAL BUCKLING 


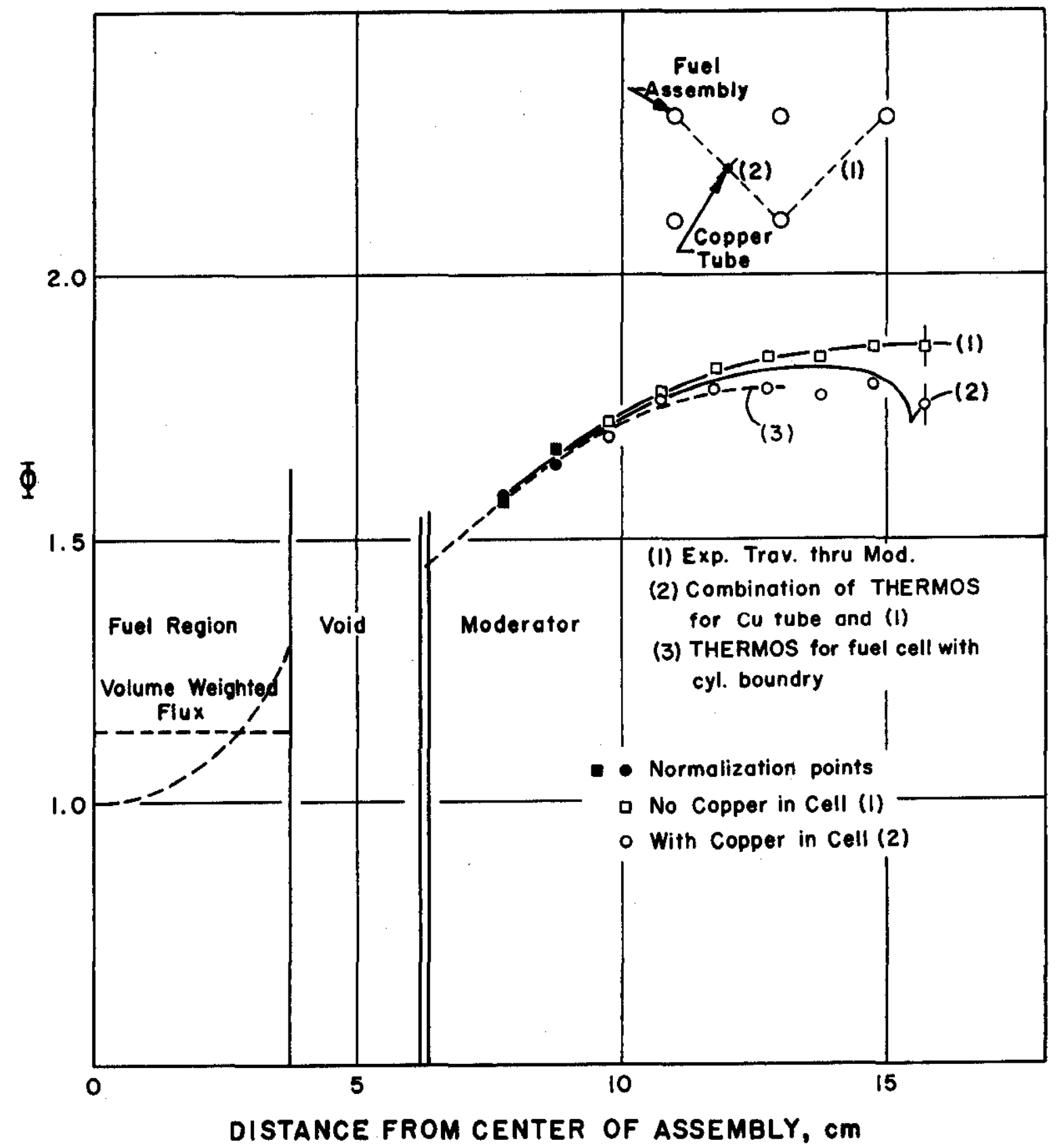

FIG. 25 CELL TRAVERSE WITH COPPER WIRE 


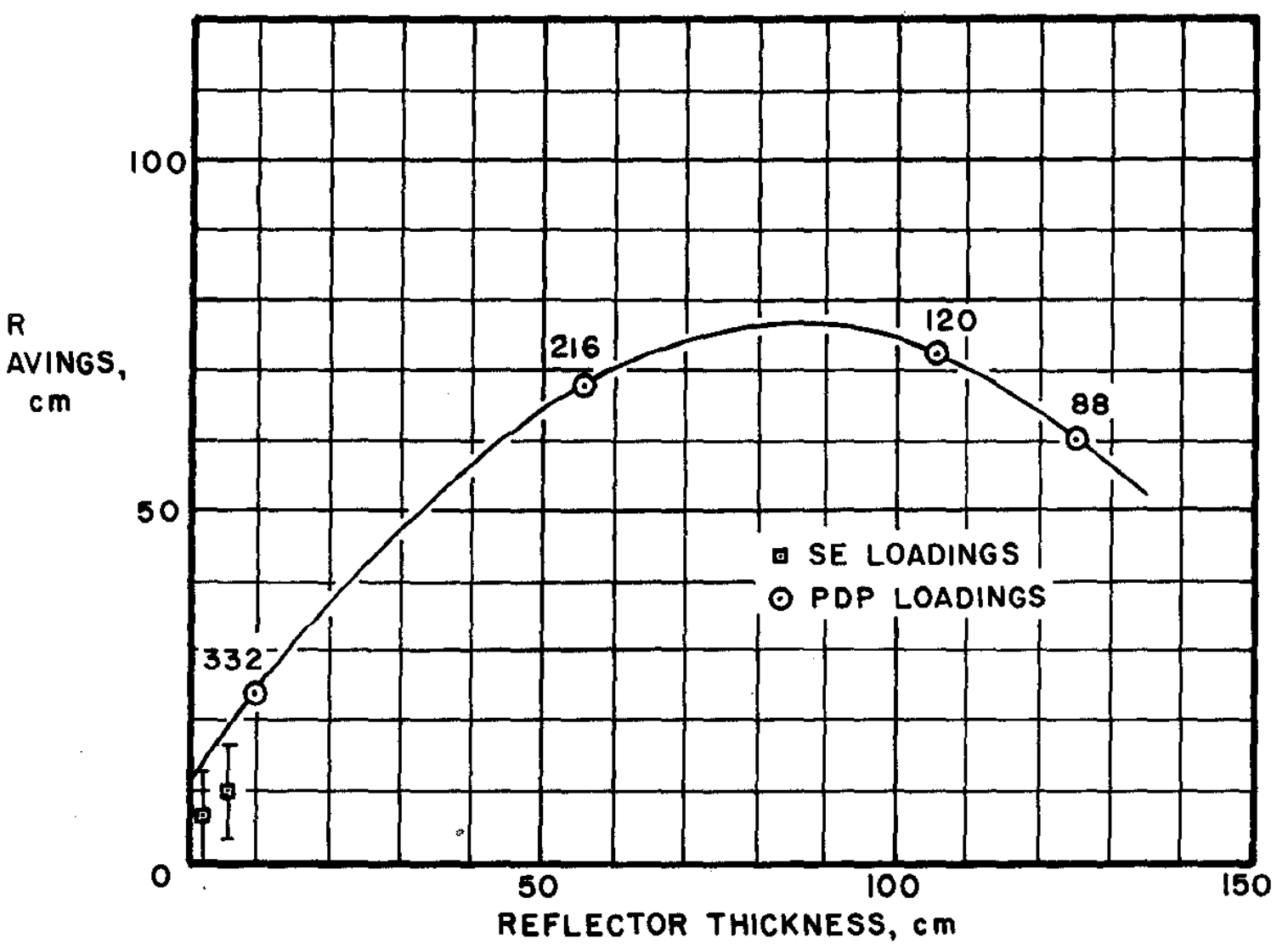

FIG. 26 REFLECTOR SAVINGS 